\title{
THE ENTRY OF THE OTTOMAN EMPIRE INTO WORLD WAR I
}

\author{
KEMAL H. KARPAT
}

\section{Introduction}

Controversy long has surrounded the Ottoman Empire's entry into the First World War on the German side because of the unusual circumstances in which it occurred. Yet, while the facts are well known, a number of vital details about the entry have been ignored or lightly explored. The first case in point is the secret alliance signed by a handful of Young Turk leaders and Germany on 2 August 1914. Just two days after overtures made by Enver Paşa on 22 July were turned down by the German ambassador in İstanbul, Hans von Wangenheim, the Kaiser overruled his ambassador for "reasons of expediency" and approved the idea of an alliance with Turkey. On 28 July the Turkish government formally presented its proposal to Germany amidst the doubts of many German leaders that Turkey was willing and able to take action against Russia.

Second, the treaty was negotiated and signed by Minister of War Enver, Minister of the Interior Talat, Minister of the Navy Cemal, and Premier and Foreign Minister Sait Halim, all bearing the title of paşa (general-minister) and Halil Mentes, the head of the House of Deputies. The rest of the cabinet and Parliament were kept in the dark. Even among the signatories, Cemal Paşa was a late convert while Halim had been slow in siding with the war party. None of the signatories, except for Enver, was a known Germanophile; rather, most Ottoman politicians and intellectuals preferred to side with France or Great Britain, the two traditional models of modernizationWesternization and presumed supporters of the Ottomans against Russia.

Third, on 29 October 1914 the Russian ports of Sevastopol and Odessa were bombarded by the 19,000-ton German battle cruiser Goeben, and the

${ }^{1}$ Ulrich Trumpener, Germany and the Ottoman Empire, 1914-1918 (New York, 1989), p. 15. On the subjectö see also Harry N. Howard, The Partition of Turkey: A Diplomatic History, 1913-1923 (Norman, OK, 1931); Keith Wilson, ed., Decision for War, 1914 (New York, 1995); Marian Kent, ed., The Great Powers and the End of the Ottoman Empire (Hempstead, 1984) and A. Haluk Ulman, Birinci Dünya Savaşına Giden Yol [The road to the First World War] (Ankara, 1972). 
5,000-ton light cruiser Breslau, renamed Yavuz and Midilli, respectively, but under the command of Admiral Wilgelm Souchon. Undertaken without the authorization of the Ottoman Parliament or cabinet, the bombardment was intended to assure "Ottoman superiority on the Black Sea," although other measures necessary to assure this "superiority" were ignored. A few ships were sunk, but Russian naval power remained intact. In reality, the strike against the Russian ports was planned with the clear aim of bringing the Ottoman state into the war, thus lightening the Allied pressure on the Western and Eastern fronts, where German (and Austro-Hungarian) forces had begun to suffer serious setback at the Marne and Galicia.

Fourth, the decision to push the Ottoman state into the war by attacking Russia was the result of converted pressure by several German military and diplomatic representatives on Enver Paşa, who after an initial desire to enter the war as soon as possible had turned dovish. The decision was made against the opposition of several high-ranking military officers closely associated with Enver at general staff headquarters. As will be indicated later, these officers were Turkish nationalists who favored entry into the war at a much later date, possibly in the spring of 1915 after Turkey had finalized its military preparations and the outcome of the war had become predictable. As Ottoman patriots, these high level officers placed the country's national interest above their German sympathies. After carrying the war burden from 1914 to 1918, many took an active part in the War of National Liberation (1919-22) and the establishment of the Republic (1923). An analysis of the role that these officers played in Ottoman-German relations will provide new clues to explain the Porte's entry into the war and the struggle behind it.

The explanations Turkish and non-Turkish scholars offer for the Ottoman entry into the war vary greatly according to the proponents' nationality and knowledge of facts. The anti-Unionist and traditionalminded Turks blame the Union and Progress Party (CUP, or Unionists) and especially its three leaders Enver, Talat, and Cemal for having dragged the Empire into a war it could not win and hence causing its disintegration ${ }^{2}$. The

${ }^{2}$ Ahmet İzzet Paşa, a veteran Ottoman army commander who became chief of staff after 1908 , then minister of war, and finally premier in 1918, represents the anti-Unionist view. He was very close to Goltz, who taught him modern military strategy and tactics. A descendent of an old Albanian feudal family that distinguished itself with service to the state, İzzet was a monarchist loyal to the Sultan but also a modern traditionalist. In his memoirs, İzzet credits Enver with bringing discipline and reforms to the army but criticizes his alliance with Germany as a surrender to Europe and the war as "a very big mistake, a betrayal and crime against the nation." Ahmet İzzet Paşa, Feryadım (İstanbul, 1982), vol. 1, p. 186. The memoirs were written in 1924 and a part published in 1928; another segment of the book was published in German in 1927. 
other Turkish view is that Germany duped the Young Turks into signing the alliance and engineered the bombardment of Russian ports, which was an almost inevitable casus belli ${ }^{3}$.

Ulrich Trumpener, who has written the most extensive book on the issue, rejects the accusation that Germany brought the Ottomans into the war for its own ends. Instead, he places responsibility on the Ottoman leaders' raison d'etat and their miscalculating German strength and the direction of the war ${ }^{4}$. Certainly, many of Trumpener's arguments are valid, but they are insufficient to explain how and why the Ottomans abandoned almost a century of friendship towards Britain and France to embark suddenly on a war against the public will.

Prior to the Young Turks' take-over in 1908, Ottoman foreign policy under Sultan Abdulhamid II had been one of friendship (or neutrality) towards all the great powers. Even after Britain and France occupied Egypt and Tunisia in 1882 and 1881, respectively, the sultan sought to maintain friendly relations with the Ottoman Empire's two traditional supporters against Russia ${ }^{5}$. Until the Young Turks seized power in January 1913, their foreign policy also remained oriented towards Europe despite their growing suspicion about the imperialist aims of Britain, France, Russia, and Italy.

The great powers, on the other hand, grew increasingly hostile to the Young Turks both for their close relations with Germany and for their firm policy of modernization, independence, and political activism, which jeopardized the powers' plans to partition the Ottoman Empire ${ }^{6}$. By contrast, Germany, whatever its own imperialist ambition, was the only European representative of Western Civilization that did not have any claims

${ }^{3}$ Enver Ziya Karal, the late head of the Turkish Historical Society, named German imperialist ambitions, ideas of racial superiority, nationalism, great power rivalry, and Ottoman internal problems as reasons for the German-Ottoman alliance and entry into the war. Osmanls Tarihi, vol. 9, Íkinci Meşrutiyet ve Birinci Dünya Savaşı (1908-1918) (Ankara, 1996), pp. 345-55.

4 Trumpener, Germany and the Ottoman Empire p. 20; also "Turkey's Entry into World War I: An Assessment of Responsibilities", Journal of Modern History 63 (December 1991), pp. 369-80.

${ }^{5}$ For Abdulhamid's foreign policy see F. A. K. Yasemee, Ottoman Diplomacy: Abdulhamid II and the Great Powers, 1878-1888 (İstanbul, 1996).

${ }^{6}$ Alan Palmer rightly notes that the Ottomans entered a more dynamic phase in 1839 with the Tanzimat (Reorganization), which gave Ottoman institutions a "vitality foreign diplomats were too prejudiced to perceive." The Decline and Fall of the Ottoman Empire (New York, 1993), p. 112. 
to Ottoman territory and offered the Turks respect as well as military and political partnership. Although a small but influential minority, echoing Mustafa Kemal (Atatürk), view the entry as an inevitable and "patriotic act," today most Turks regard the Young Turk leaders inexperienced, powerhungry adventurers who "dragged the might Empire into war and destroyed it."

In fact, the Ottoman entry into World War I could be better understood if viewed not solely as the short-range product of foreign policy consideration but also paradoxically, as a result of the Ottoman elites' century-long search for modernization, economic independence, and acceptance into the comity of European nations. It consequently stemmed from a complex cultural-political process that transformed the Ottoman political elite from defenders of the state's classical socio-political order into its critics and reformers. In the course of that transformation, members of the elite redefined themselves as the spokesmen of the "millet" or nation, that is, as the representatives of a secularized political community, regardless of the latter's different concepts of nationhood.

The British and French helped orient the Ottoman state towards capitalism and centralized government, but they turned against the Turks as modernization strengthened the Ottoman state against Russian, French, and British partition plans. Still, a substantial portion of the Ottoman modernist intelligentsia gradually made it their primary goal to become part of contemporary European civilization.

Many Young Turks regarded the Triple Entente and Triple Alliance as vehicles of Europeanization. They formally sided with Germany late in the summer of 1914, only after Britain, France, and Russia rejected their proposals for alliance and assurances of territorial integrity. Germany was the last and unavoidable choice, but it was still European, modern and developed.

The second reason for the Young Turks' entry into World War I was the emergence of ethnicity as the basic determinant of political identity and

${ }^{7}$ Tevfik Çavdar, Talat Paşa. Bir Örgüt Ustasının Yaşam Öyküsü (Ankara, 1995), pp. 325-6, quotes at length Atatürk: "Turkey had to participate in the past war and the participation as carried out by the government was correct.... The timing, conduct of the war can be criticized but not the principal [decision]." Çavdar, who wrote a good biography of Talat Paşa, rejects the view that the trio of Enver, Talat and Cemal arbitrarily brought the Ottoman state into the war. 
national statehood. The fundamental social unit in the classical Ottoman state had been the religious community. Ethnicity had been submerged in a non-political religious identity until the rise of nationalism reversed their order of priority and designated a real or imagined historical territory as the fatherland. Nationalism arose first among the Orthodox Christian groups, most of which became independent in 1878, while the Muslims clung to the idea that they formed a single group bound by religious ties. When the outbreak of the Albanian revolts in 1910 and the Arab unrest of 1911-13 challenged that idea, the Young Turks implicitly renounced the official Ottoman Islamist policy and sided with the most numerous, though hitherto ignored, ethnic group, the Turks. Afterwards, the Young Turks became truly Young Turks, openly using the state to create a politically conscious Turkish nation. The war in man ways in advertently helped consolidate this process of turning the multi-ethnic Muslim society of Anatolia and whatever was left of Rumeli (the Balkans) into a Turkish nation, a process that has continued to date.

The third internal reason for the Ottoman entry into the war was a consequence of the relatively liberal political ideology that brought the Young Turks to power in 1908. Freedom brought forth a variety of pent-up demands, aspirations, and complaints, undermining the unity among the major ethnic and social groups. As a result, the Young Turk leaders hoped that entry into the war would stimulate patriotism, reestablish a degree of unity and justify their strong rule. Intended to create a "responsible political system aware of the basic needs of the nation," their "democracy" was an elitist system that ignored many liberties and contradicted its own populist spirit and liberal aspirations.

Finally the demand for full economic independence was another key goal prompting the Ottoman entrance into World War I. Abolishing the capitulations and treaties that had granted the European powers extensive economic privileges and extraterritorial rights was deemed, absolutely essential to modernization.

By bringing the Ottoman state into war, the four considerations just summarized decided its fate and paved the road for Turkey's emergence as a national state. Consequently, they demand further historical, political, and cultural analysis. 


\section{The Reliance on and Estrangement from Europe: A Background}

In the 1830s Egypt's defeat of the Ottoman armies, led Britain, France, Russia, and Austria begin debating the "Eastern Question" of how to end the Ottoman Empire and partition its lands. At the outset of Ottoman relations with Paris and London in the sixteenth century the Porte had given both powers trading rights in the Ottoman lands, known as ahdname in Turkish and as "capitulations" (from capitola, or chapter) in Europe. In 1798, however, Napoleon's occupation of Egypt brought about a de facto BritishOttoman military alliance against the French, who had disrupted the social order of Egypt and allowed Mehmet Ali, an officer in the Ottoman army to become viceroy (Hidiv) of Egypt in 1805. Although recognizing the suzerainty of the sultan in İstanbul, Mehmet Ali used French help to build a modern army. He then financed his army by converting the Egyptian economy into a state-run, quasi-capitalist system based on cotton cultivation, which eventually supplied raw material to the British textile industry.

Between 1831 and 1833, Mehmet Ali turned against his suzerain and, after repeatedly defeating the Ottoman armies, occupied Syria and southern Anatolia. The Ottoman armies already had suffered a series of defeats at the hands of the Russians and Austrians between 1768 and 1812, but those defeats had not threatened the basic fabric of the Ottoman state as Mehmet Ali's victories did. After his troops, under the able command of his son İbrahim paşa, had occupied the Muslim Holy Lands, they prepared to march on İstanbul. Threatened from within by his Muslim vassal, the reigning Sultan Mahmud II requested help from the Russian tsar, who send 15,000 troops to İstanbul.

The Eastern Question took a definitive course with the Hünkar İskelesi treaty of 1833 although its beginning usually is dated to $1774^{8}$. In any case, Britain recognized the Russian advance as threat to its expanding trade in the eastern Mediterranean and responded with what came to be known as the Palmerston doctrine from Lord Henry John Temple Palmerston, foreign minister, 1831-41 and 1846-51, and prime minister, 1855-58 and 1859-65. The doctrine held that the integrity of the Ottoman Empire assured the security (and possibly the survival) of the British Empire; the British also

\footnotetext{
${ }^{8}$ M. S. Anderson, The Eastern Question, 1774-1923: a study in international relation (London, 1966).
} 
believed that the Ottomans needed to reform their system, though never to become strong enough to challenge the British.

After the British landed troops in Lebanon, the Russians evacuated the Straits, and Mehmet Ali's troops retreated to Egypt as a consequence of the London Treaty of 1841. In the meantime, the new sultan Abdulmecid issued the famous Tanzimat Ferman1, or Reorganization Edict of 1839, which is regarded as the beginning of the Ottoman reform movement in fact. The Ottoman reform movement had begun around 1800 under Selim III, ${ }^{9}$ but the Tanzimat Edict was the first serious attempt to reorganize state institutions on the European centralized model. Reşit Paşa (d. 1858) the former Ottoman ambassador in London became the driving force behind the reforms and a British friend as was the sultan himself.

Between 1839 and 1844, the Ottoman government regained control of Syria and Arabia, thanks to the British support that followed the extensive economic, trade and financial privileges granted to Britain in the Commercial Treaty of 1838 . This commercial treaty was in a good measure a voluntary effort designed to adjust the Ottoman economic and legal systems to the requirements of capitalism, which already was transforming the Ottoman culture and social structure and affecting relations between the ruler and the ruled.

The Crimean War and the Paris Peace Treaty of 1853-56 marked a turning point both in Ottoman relations with Britain and France and in Ottoman internal policies. Because the European coalition that fought the Russians in the Crimea included the Ottomans, for the first time OttomanMuslim soldiers fought shoulder-to-shoulder with Catholic and Protestant French and British troops against Orthodox Christian Russian forces. While the reservations of the Ottoman Muslims towards the civilization of Christian Europe were swept aside, the British proudly told their Muslim subjects in India that Britain was helping the caliph, the head of the Muslim

\footnotetext{
${ }^{9}$ There is abundant literature on the Tanzimat period. The classic work is Ed Engelhardt, La Turquie et le Tanzimat, ou, Histoire des reformes dans l'Empire Ottoman depuis 1826 jusqu'a nos jours, 2 vols. (Paris, 1882-1884). Others are Tanzimat, 1940, a Turkish centennial commemorative; Enver Ziya Karal, Osmanls Tarihi, vol. 5, (1789-1856), (Ankara, 1947); Bernard Lewis, The Emergence of Modern Turkey (London and New York, 1961); and Stanford Shaw and Ezel Shaw, History of the Ottoman Empire and Modern Turkey (Cambridge, 1977), vol 2, pp. 445-53.
} 
community, against the Russians. National interest prevailed over religious loyalty.

The Paris Treaty of 1856 recognized the Ottoman state as subject to international law. In other words, it allowed the Ottoman government to operate within a European frame of reference in establishing diplomatic relations, mutually binding treaties, etc ${ }^{10}$. Above all else, however, if forced the Russians out of Wallachia and Moldavia and forbade the tsar to keep warships and build naval bases on the Black Sea.

In exchange for inclusion in the community of "civilized" nations, the Ottoman government accepted the Islahat Fermanı (Reform Edict). Prepared entirely by the British, French, and Austrians, the edict dealt mainly with the status of the Christians in the Ottoman Empire ${ }^{11}$. Previously, throughout its existence, the Ottoman government had recognized the individual only as a member of a religious community that represented the individual's rights and acted as the intermediary between the government and the individual. Now the edict wept aside the religious community and empowered individual Christians to address the government and ask for "rights" as individuals. By contrast, the Muslims maintained their old communal organization, although secularization of the legal and educational systems subsequently produced laws that addressed them, too, as individuals.

The Western powers that had signed the edict appeared to be the spokesmen and guarantors of the Christians' rights. Even Russia, defeated in the war, retained its right to "make representation on behalf of the Orthodox Christians" from the Küçük Kaynarca Treaty of 1774. For the victors, the Treaty of Paris and, indirectly, the Reform Edict of 1856 opened the way to a rapid increase of economic and judicial privileges followed by the rapid growth of a rich domestic Christian middle class. Soon, in order to modernize its communication infrastructure and the military, the Ottoman government began to borrow heavily from Europe.

10 All these issues are debated in this author's book, The Politicization of Islam: Reconstructing Identity, State, Faith, and Community in the Late Ottoman State (Oxford-New York, 2001).

${ }^{11}$ See Roderic H. Davison, Reform in the Ottoman Empire, 1856-1876 (Princeton, 1963). 
Before 1855 Ottoman exports had been higher than imports, and the state was free of foreign debt. By the end of the century, the government had become a net importer burdened with a huge debt; the payment of interest alone amounted to 34 percent of the national budget ${ }^{12}$. Yet it would be incorrect to attribute the economic dependence of the Ottoman government entirely to European greed. Because Ottoman arms factories were unable to keep pace with European technology, the government had to borrow huge sums at high interest to pay for arms purchases abroad. Moreover, the ostentatious new consumption habits of the burgeoning middle classes, including travel abroad, intensified their commerce with Europe. For a variety of reasons, then, by the 1870 s the old capitulations had turned into oppressive instruments that were used by the European powers to increase their economic, legal, and political privileges and their pressure on the Porte.

At the same time, the new Greek and Armenian middle classes sought the protection of the European embassies and consulates, which granted many of them British or French citizenship, even though they had been born Ottoman, exacerbating tensions between Muslims and Christians ${ }^{13}$. Formerly, the segregation of the population into social estates and communal religious organizations (the millet system) allowed the government to maintain balance and achieve confessional peace among its diverse population. Now the emergence of the new market-oriented middle classes, fed by bottom-to-top mobility, and the steady secularization of the government institutions, changed the old, predominantly religious identities into secular, ethnic-oriented ones, first among Christians and ultimately among Muslims.

The rising consciousness of the Orthodox Christians acquired an ethnic dimension quite rapidly, thanks to pan-Slavist ideology propagated by the tsar's agents and the Christians' own reading (or, rather, misreading) of Western nationalist literature. The modernist intelligentsia of 1860s, known as the Young Ottoman, expressed the Muslim reaction to these developments. They paradoxically blamed their government both for

12 Donald C. Blaisdell, European Financial Control in the Ottoman Empire (New York, 1966).

${ }^{13}$ From the Black Sea port of Giresun, at the end of the century the rich Greeks often sailed to France and bought outfits to wear in the annual festivities of their native towns. 
tampering with their traditional socio-political system and culture and for not adopting a constitution and a European type of government. The desire to remain an authentic Ottoman and become "modern" became an ideological slogan. The claims of the Young Ottomans led to the ouster of the autocratic Sultan Abdulaziz as well as to the introduction of a constitution in 1876 and the convening of a House of Deputies ${ }^{14}$. Thus, with a stroke, the unprecedented idea of popular political participation was given constitutional recognition. The constitution, it was hoped, would permit the Christians to participate in law making and so induce them to become true Ottomans and renounce their nationalist claims ${ }^{15}$.

At the same time, the intelligentsia came to believe that hürriyet (freedom) was an essential condition of modern or contemporary civilization. "Freedom, we have become thy slaves," wrote an Ottoman poet. In this way, freedom as an ideology designed to fight absolutism and its representative, the sultan, became part of the Ottoman Muslim intelligentsia's concept of contemporary civilization. It was a driving ideological force that they hoped would supercede differences of faith, create internal unity, and preserve the integrity of the multi-ethnic, multireligious Ottoman state.

Meanwhile, unable to expand into Eastern Europe and Anatolia, Russia shifted its attention to conquering the Central Asian states between 1865 and 1873. With Russia now poised to march towards India, the Ottoman state took on new importance for the British. The Ottoman sultans had acquired the title of caliph, or Khalife-i Resullah (Successor to God's messenger), around 1518. But for reasons too complex to discuss here, they did not make much use of it until the British pointed out its political potential $^{16}$.

14 The best source on this little-researched subject is Robert Devreux, The First Ottoman Constitutional Period (Baltimore, 1963).

${ }^{15}$ Kemal. H. Karpat, An Inquiry into the Foundations of Nationalism in the Ottoman State (Princeton, 1973).

${ }^{16}$ The Küçük Kaynarca Treaty of 1774 allowed the Muslims of Russia to cite in their Friday prayers the name of the Ottoman sultan as their caliph. Some scholars regard this date as the beginning the caliphate's transformation into a political force-see Gilles Veinstein, La Question du Caliphat (Paris, 1994). My own extensive research indicates that the caliphate's true politicization began in the 1860 s and was due to international circumstances. 
Keenly aware that the Muslims of India resented the force by which London had undermined the power of the Mogul sultans and other Muslim rulers to take over the subcontinent, the British did their best to demonstrate that they were not the "enemies of Islam." To this end, in the 1790 s they had argued to the rebel Sultan Tipu of Mysore that the caliph in İstanbul, the "head of Islam," was their friend and ally. Then, in 1857 they had persuaded Sultan Abdulmecid to call on the sepoy to put down their arms, and as the Russians prepared to advance into Central Asia in the 1860 s, the Ottoman bureaucrats had approved Britain's efforts to unite the Muslims of Central Asia into a sort of confederation headed by the caliph. The scheme described by the Ottoman historian Cevdet Paşa never became a reality, however, because the British wanted to establish the confederation by themselves and because all the disparate Muslim tribes proved too difficult to bring together ${ }^{17}$.

British policy towards the Ottoman state changed drastically in the 1870s. German unity, the defeat of France, and the emergence of Germany as a world power destroyed the balance of power established by the Paris treaty to the detriment of the Ottomans. France had become the Porte's main supporter against Russia, thanks partly to the Francoophile Ottoman premier Ali Paşa (d. 1871). Now the eclipse of France enabled Russia to push aside the provisions of the Paris treaty prohibiting its military presence in the Black Sea and so to regain its influence in Eastern Europe.

Russia became especially involved in the affairs of the Balkans. The Serbian and Bulgarian revolts of 1875-76 stemmed in part from Ottoman inability to understand the force of nationalism among the Balkan Christians as well as from Russian and Austro-Hungarian machinations. Those uprisings internationalized the nationality conflicts, destabilized BritishOttoman relations, and turned British public opinion against the Turks ${ }^{18}$. At the ensuing Constantinople Conference of December 1876, whose main purpose was to grant autonomy to the Balkan countries, the Sublime Porte's

17 Başvekalet Arşivi (Prime Minister's Archives), Yıldız collection, sec. 14, carton 38, doc. Nu553/618 ca 13 February 1894. The memo was addressed to Sultan Abdulhamid II. Relations between the Ottoman Empire and Britain are studies by Allan Cunningham, Anglo-Ottoman Encounters in the Age of Revolution ed. Edward Ingram (London, 1993).

18 William L. Langer, European Alliances and Alignments, 1871-1890 (New York, 1950); Mihailo D. Stojanovic, The Great Powers and the Balkans, 1875-1878 (Cambridge, 1939); A. Emin Yalman, Turkey in the World War (New Haven, 1930). 
refusal to accept the conference's recommendation alienated Britain, France, Austria-Hungary, and the European public.

The Ottomans' international isolation was almost total by spring of 1877. Having achieved a goal, its diplomacy had pursued since 1870, Russia launched an unprovoked attack on the Sublime Porte to start a war that, in turn, led to the Balkan War and eventually to Ottoman entry into World War I. In fact, the Ottomans viewed the war of 1877 as having given Russia its opportunity to put an end to the existence of the Ottoman state. Likewise, the memoirs of the Young Turk leaders and intellectuals agree that Russia welcomed the outbreak of World War I as its chance to settle the final score with the Turks and the Austrians.

An often-overlooked detail of Ottoman-British relations was the emergence of the popular press with its capacity to mobilize the public. In the Ottoman state, the newspaper Basiret (published 1869), the first massoriented publication, had supported Germany against France in 1870 and was rewarded by Chancellor Otto von Bismarck with money and modern printing facilities. Later it called on all Muslims to defend the caliph's land and Islam against the Russians, ingraining in the Ottoman mind a portrait of Russia as the archenemy of the Turks and of Islam, although Muslims in Russia actually enjoyed some freedom. Basiret was pro-British, but its appeal of Muslims still unsettled some British liberals who had supported the cause of the Balkan Christians and decried the British alliance with the Ottoman Empire in the Crimean War of 1853.

In Britain the famous "liberal" leader William Gladstone used the press to portray Prime Minister Benjamin Disraeli of the Conservative Party, a converted Jew, as having pro-Turkish feelings. Gladstone charged that Disraeli hates Christian liberty and reconstruction. He supports old Turkey, thinking that if vital improvements can be averted, it must break down. Britain then could take its share without cost or trouble ${ }^{19}$. In a famous pamphlet that accused the Turks of having massacred 60,000 Bulgarians while suppressing the uprising of 1876 , Gladstone expressed a common

${ }^{19}$ John Morley, The Life of William Ewart Gladstone (New York, 1903), 3. vols. vol. 2, p. 549. See also Bernard Lewis, "The Pro-Islamic Jews", Judaism 17 (1968), pp. 391-404. Much of what has been written here is supported by Sir Roy Jenkins, Gladstone (New York, 1997). Jenkins states (p. 500) that Gladstone had a sense "perhaps even a subconscious one of the superiority of white Anglo Saxon men". 
belief of the British liberal establishment that Turks should not be trusted, protected, or treated as equals, for they could not share the values of European civilization ${ }^{20}$.

On the eve of the Russo-Turkish War of 1877-78, the British ruling establishment thought the Ottoman refusal to grant some autonomy to the Balkan Christians stemmed from an obstinate, unrealistic desire to preserve a "decaying" empire. Although a number of Europeans, including knowledgeable scholars such as Arminius Vambery, believed that the Turks were sincerely engaged in modernization, the British let their own wish to see the Empire disintegrate obscure any progress. In fact, the Ottomans had adopted a constitutional system, had begun to provide three levels of public education, had encouraged European investment, and had developed a relatively free press.

Some Ottomans though Britain welcomed the Russian war of 1877-78 because it would be quell the Ottomans' own nationalist upsurge and force the Sublime Porte to accept London's lordship over the Ottoman Empire in exchange for British support. Because Britain declared its neutrality in the war and refused to sell arms to its Ottoman "friends," the Balkan provinces of Serbia, Montenegro, and Romania became independent, and Bulgaria obtained extensive autonomy, after killing or sending into exile two-thirds of its non-Bulgarian Muslim population ${ }^{21}$. The Berlin Treaty of 1878 , thanks to London's pressures, restored Ottoman rule over Macedonia, Thrace, Albania, and Kosovo, but the sultan was forced to cede Cyprus to the British, supposedly in exchange for their defending his empire against Russian ambitions.

British-Ottoman relations continued to worsen despite the appointment of Henry Layard, one of the few remaining Turcophiles in the Foreign Ministry, as ambassador to İstanbul. Assure of Ottoman dependence, the British revived their old scheme of using the caliphate to promote their foreign policy objectives. In 1877-78 Layard and the Earl of Lytton, viceroy of India, persuaded the new sultan-caliph, Abdulhamid II, to send a mission to convince ruler Sher Ali of Afghanistan to establish a "Muslim front" against

${ }^{20}$ W. E. Gladstone, Bulgarian Horrors and the Question of the East (London, 1876); David Harris, Britain and the Bulgarian Horrors of 1876 (Chicago, 1939).

${ }^{21}$ Justin McCarthy, Death and Exile: The ethnic Cleansing of Ottoman Muslims, 1821 1922 (Princeton, 1995). 
Russia and, in the process, to accept British rule of his land. The mission did not succeed but gave the Muslims of India an opportunity to express their love and loyalty to the caliph, alerting the British that the caliphate could be turned against them ${ }^{22}$.

In Britain, Gladstone's liberal Party defeated Disraeli's Conservatives in the election of 1880, fought largely over British foreign policy and relations with the Ottomans in particular. When the Grand Old Man became prime minister, British policy towards the Ottoman state moved from the theoretical planning of partition to actual implementation. In 1881 Britain supported, if not encouraged, France's occupation of Tunisia, and in 1882 Britain occupied Egypt. The British also began to court the Arab sheiks of the Gulf and the emirs of Mecca, hoping to replace the Ottoman caliph with an Arab one more amenable to their views.

\section{The Reign of Abdulhamid II and the Struggle to Assure the Survival of the Ottoman State}

The war of 1877-78 had left the Ottoman state on the brink of disintegration. The relatively rich Balkan provinces were lost; the economy was burdened by heavy foreign debt and a war indemnity to Russia; the army was incapacitated and the Arab provinces that still belonged to the Empire were especially restive. Also, British consular reports from dozens of Anatolian and Balkan cities indicate that the losses in the war had demonstrated to the Ottoman Turks that their underdevelopment and misfortunes were due to the shortcomings of their own leaders. The obedient and resigned Muslim population apparently had become ready to follow new political paths to better their lives and assure the survival of their state $^{23}$. In addition, it was clear to many Turks that their salvation lay in self-

${ }^{22}$ Ram L. Shukla, Britain, India and the Turkish Empire, 1853-1882 (New Delhi, 1973); Azmi Özcan, Pan-Islamism: Indian Muslims, the Ottomans and Britain, 1877-1924) (New York, 1997).

23 A consul reported that "some years ago Mohammedans were kept in ignorance of all political upheavals and appeared indifferent to their results," but the "progress of education...the development of a native press, the introduction of Western civilization and the growing facilities of communication have gradually awakened a spirit of inquiry among this people. They now take a keen interest in national and foreign political affairs." The report noted that "the European public does not hear much of this, as the Turks, unlike the Christian nationalities... have not the means of propagating their views abroad through foreign newspapers" and concluded "the people in general look upon England and France as enemies of their religion and existence." Foreign Office (hereafter FO), London, 424, vol. 126, p. 18. Earlier, Consul Herbert Chermside had reported to London that he was struck by the "definite expression of public opinion, often most revolutionary that has permeated to the most out of the way hamlets... There is a strong feeling of resentment against the Constantinople government and the pashas [ministers] in general. It really seems to have come home to the 
reliance, progress and unity, for their trust in British support had vanished. These were the ideological underpinnings of the Young Turks' search for change and modernity.

Sultan Abdulhamid similarly believed that the Empire's survival lay in the achievement of internal unit, rapid material progress, peace with all countries at all costs, and an end to European intervention in Ottoman affairs. Nevertheless, he regarded Britain as the most powerful nation on earth, capable of blocking Russian and French ambitions, so he intended to persuade the British to return to Palmerston's policies of mutual support in ruling the Muslims and opposing Russia. A firm believer in absolutism while also an admirer of Western civilization (minus its ethnic nationalism and individualism), the sultan suspended both the constitution and Parliament in 1878. He then assumed direct control of all government affairs, most notably foreign affairs, and began to build a modern infrastructure of railroads, highways, and schools within his realm.

The greatest contribution of Abdulhamid to Turkey's modernization was his extraordinary expansion of the educational system. The existing sibyan or elementary schools, which offered religious education, were transformed by 1903 into European-type schools, where instructors trained in modern teachers colleges replaced the religious men. Enrollment soared from roughly 200,000 in the 1870 s to about 850,000 in 1903 . Politically speaking, however, the most meaningful educational expansion occurred at the mid-and mid-upper levels. The number of mid-level rüşdiyes in 1876 was approximately 420 with an enrollment of about 20,000 students; by 1908 it rose to about 619 schools with over 40,000 students while there were 109 idadiyes, which offered higher training, sometimes in combination with the rüssdiyes ${ }^{24}$. The curricula consisted mainly of secular subjects, although after 1892 courses on Islam were introduced. These modern schools trained a new intelligentsia with European modes of though and aspirations.

From the viewpoint of this study, the most significant educational reform was the establishment of a series of professional schools in law,

nation that with a brave and devoted soldiery and a magnificent country, they are yet in a hopeless state of ignorance, poverty and disorganization." FO 242, vol. 71, pp. 85-86.

24 The study of education in the Ottoman state is at a mere beginning. See Benjamin C. Fortuna, Imperial Classroom: Islam, the State, and Education in the Late Ottoman Empire (New York, 2002), Mehmet Alkan, Ölçülebilen Verilerle Tanzimat Sonrası Osmanlı Modernleşmesi, Ph.D. İstanbul University, 1996. 
agriculture, administration, trade, and medicine (along with some 34 teachers colleges). To cite just one example of the impact, the justice system was secularized as the $k a d l$, or judges in the traditional religious medreses, were replaced by graduates of secular law schools ${ }^{25}$. Military training also was upgraded, and the military rüşdiyes (some 25 in 1903) were topped by a war college (harbiye) and staff school. Still, in spite of his modernist policies, Abdulhamid is known in the West primarily as Islamist (or "pan-Islamist").

In truth, Abdulhamid's Islamism was a desperate policy born of necessity. The sultan appealed to the Ottoman Muslims' common culture simply to preserve the integrity of the state. Specifically, he sought to prevent the Arabs from seceding and to rally the moral support of overseas Muslims against British and French attempts to partition the Ottoman lands.

Abdulhamid emphasized that it was his religious obligation to preserve the dignity of Islam and uphold the religious rights of all Muslims. He did so by emphasizing that he was the caliph, that is, the head of the universal Muslim community rather than the mere custodian of the Muslim holy cities of Mecca or Medina, as were most of his predecessors. By thus upholding the virtues of Islam in the midst of despair and pessimism, he prevented extremists from assuming the mantle of religion to spread their political doctrines.

Addressing the British in particular, Abdulhamid implied that as caliph he could call the Cihad, or holy war, and so incite Muslims to rebel should their British, French, or Russian masters attack the Ottoman lands. In fact, he never called and probably never intended to invoke the Cihad, or to establish a Muslim Union, ${ }^{26}$ for he realized that the threat was more effective that the actual call. Instead, the caliph sent special envoys to secure the moral support of Islamic leaders, notables, writers and journalists throughout the Muslim world and increase the British fears of his caliphal influence among world Muslims.

${ }^{25}$ Both Shaw and Shaw and Bernard Lewis have referred to Abdulhamid's modernist policy, but their views have been ignored. There is now a new effort by Turkish scholars to reassess Abdulhamid's modernist role. An account of Abdulhamid's time and the writings about him are to be found in Karpat's Politicization of Islam.

${ }^{26}$ The view that pan-Islamism had a self-defensive purpose was expressed in a seminal article by Dwight E. Lee, "The Origins of Pan-Islamism", Amerikan Historical Review 47 (January, 1942). A recent book accepting the old image of pan-Islamism is Jacob M. Landau, The Politics of Pan-Islam: Ideology and Organization (Oxford, 1990). 
By 1882, the British had begun to develop an almost pathological fear of Muslim revolt in India so Abdulhamid made the subcontinent the prime target of his caliphal calls, providing asylum to dissidents and creating the illusion that he had a great following in India. These were desperate acts of weakness that nevertheless intensified the British fear that the caliph (or any other clever party) could exploit Islam to challenge their colonial rule. British Field Marshall Horatio Herbert Kitchener believed to the end of his life that whoever controlled the caliphate and the leading Muslim religious leaders could control the Muslim masses and that a major European power such as Germany could manipulate the caliph for its own interest ${ }^{27}$. Similarly, John Buchan's novel Greenmantle (1916) depicted Germany's use of a Muslim prophet to destroy Britain. (Such distorted and manipulative views of Islam resemble some post-September 11, 2001, perceptions of the faith as anti-Western.

From 1880 to 1885, Great Britain and France engaged in a furious campaign to destroy the influence of the Ottoman caliph ${ }^{28}$. Questioning the right of the House of Osman, or Turks, to hold the caliphate and asserting it belonged to the Arabs, they courted in particular the emir of Mecca and the Awns family, who claimed descent from the Prophet. In 1916, they finally convinced Sherif Hüseyin (the ancestor of the Hashemite rulers of Jordan and Iraq) to rebel against the Ottomans).

On the other hand, after Kaiser Wilhelm II visited the Ottoman lands and declared himself "friend of the Muslims," the Cihad occupied an important place in the plans of the Germans and Young Turks for World War I. Baron Max von Oppenheim, who had spent three decades in the Muslim countries and had written extensively on pan-Islamist, concurred with the German ambassador to the Porte that Turkey could be used to incite revolts in India and tie down much of the British army and navy ${ }^{29}$.

27 David Fromkin, A Peace to End all Peace (New York, 1989). This is an excellent source for British and French policies in the Middle East and World War I and their vision of Islam.

${ }^{28}$ See S. Tufan Buzpinar, "Abdulhamid II, Islam and the Arabs: The Cases of Syria and the Hijas 1878-1882", Ph.D. dissertation, University of Manchester, 1991.

${ }^{29}$ Landau, The Politics of Pan-Islam, passim. 


\section{The Young Turks: The Modernist-Nationalist Ottomans}

The Young Turks, or Unionists, were first and foremost products of the professional schools founded by Abdulhamid. Although they came to embody the reaction against the sultan's absolutism and the hope to end the country's underdevelopment, they still accepted the policy of OttomanismIslamism that the sultan had used to hold together his multi-ethnic, multireligious Empire. In other words, they aimed to achieve modernization and also to hold the Empire together with obsolete imperial ideas that could not compete against the nationalism, individualism, and secularism of the modern age. Their knowledge of the country and the world had not come from practical experience but from their textbooks, many of which originated in Europe, and from a variety of literary works. The reading in the schools of such "banned"-yet freely circulated-political literature as the works of Namık Kemal, Western political writings, and domestic pamphlets glorifying freedom and civilization that nurtured the intellectuals prepared the Young Turks for their modernist and nationalist mission. Because the Young Turks accused Abdulhamid of using the caliphate to consolidate his authority and absolutism, their criticism culminated in demands that the sultan restore both the constitution and Parliament.

Political freedom and constitutionalism were the moving ideas behind the first secret political organization established in 1889 by the students at the military medical college. After they were discovered by the sultan's secret police, many members of that organization escaped abroad and in about 1895 established in Paris the Committee of Union and Progress, which soon turned into a sort of debating society. Its domestic branch, known initially as the Freedom Society, was organized in Salonica in 1906. The founders were Talat, then a postal worker, some intellectuals and especially army officers long exposed to the propaganda of the Bulgarian, Greek, and Serbian nationalists who coveted Macedonia. Consequently, it is no exaggeration to claim that the Young Turks who carried out the revolution of 1908 represented the products of, as well as the reaction to, Balkan nationalism. The revolution began as a show of insubordination to the sultan's orders and ultimately forced the sultan to reinstate the Constitution of 1876 and to convene Parliament on 24 July $1908^{30}$.

\footnotetext{
${ }^{30}$ Feroz Ahmad, The Young Turks (Oxford, 1969).
} 
The Young Turks inherited Abdulhamid's foreign policy, his balanced relations with Germany, Britain, France, and Russia, and his ideology of Ottomanism, that is, the preservation of Ottoman territorial integrity. Prior to 1908 , Ottomanism had envisaged the creation of a common identity for all the Ottomans, regardless of faith or ethnic differences. After the revolution, however, emphasis shifted to assimilating the entire population into an Ottoman Islamic nation. In other words, the Young Turks were Ottoman nationalists before they turned towards Turkish nationalism, whereas Abdulhamid had favored an Islamic Ottoman patriotism but formally opposed ethnic nationalism. It is at this juncture of history that Ottoman-German relations acquired new dimension.

Ottoman relations with Germany had developed rapidly after 1878, as Berlin appeared to be a potential counterbalance to Britain and Russia and a promising source of military help. For the following three decades, German military aid and training allowed Berlin not only to professionalize the Ottoman army according to its own military philosophy, but also to assess the Turks' capabilities.

Colmar von der Goltz, head of the German military mission from 1883 to 1895, trained Ottoman army officers and wrote textbooks for them he believed that Turkey's salvation lay in the union of the village folk, who had preserved the basic qualities and spirit of the old Turks, with the military elite trained in the modern sciences ${ }^{31}$. Goltz developed very high esteem for the Turkish soldiers and made many loyal friends among their officers, including Ahmed İzzet, Mahmut Muhtar, and Ali Riza Paşas, all ministers or high officials in the Young Turks' government, as well as Pertev Demirhan, Goltz's biographer.

Goltz did not place his hopes for the resurgence of the Ottoman Empire in the constitution or in the absolutist rule of Sultan Abdulhamid, whom he

${ }^{31}$ Colmar Freiherr von der Goltz, "Stärke und Schwäche des Türkischen Reiches", Deutsche Rundschau 93 (1897), pp. 95-113. Goltz, who spend many years in Turkey and died there in 1916, deserves a careful study. F. A. K. Yasamee, "Colmar Freiherr von der Goltz and the Rebirth of the Ottoman Empire", Diplomacy and Statecraft (July, 1997), pp. 91-127, is an excellent assessment of early German influences in Turkey. On the Young Turks and their philosophical outlook, see M. Naim Turfan, Rise of the Young Turks: Politics, the Military and Ottoman Collapse (New York, 2000), Erik J. Zürcher, The Unionist Factor, The Role of the Committee of Union and Progress in the Turkish National Movement, 1905-1926 (Leiden, 1984). 
disliked, but in a strong leader dedicated to progress and to his people. He believed in the rejuvenating capacity of war, which relied on initiative, courage, discipline, fearlessness, and self-sacrifice (all present in the Turkish soldier) rather than on technology. He also began to believe after 1890 that world economic competition would lead to a world war, involving Britain and Germany, and that Turkey could become a powerful factor in world policy.

Outside the officer corps, however, the Germans were not popular either with the Ottoman intelligentsia and public or with the army as a whole. The majority of the intelligentsia seemed to prefer the French and pictured the British as fair and respectful of human rights. For instance, writer Omer Seyfeddin, son of an army officer, in his short story "Von Sadriştayin" portrayed the Turkish imitators of "things German" as deprived of national pride and true culture. One can even say that had it not been for the almost forced estrangement of the Ottoman leaders from the West in the summer of 1914, the country would have stayed with the Allies, although the lower classes seemed to develop a liking for the Germans' discipline and vigor.

Until 1913, the Young Turks continued the "neutrality" initiated by Abdulhamid. Firmly believing that the European powers were headed for an armed conflict, the sultan did not want the Ottomans to commit themselves militarily to any one of them despite the country's close ties to Germany ${ }^{32}$. Because the Young Turks did not initially assume direct control of the government, they relied on the sultan's old staff. As premiers, Sait and Kamil passas, continued the Empire's traditional good relations with London and Paris, overlooking the latter's growing friendship with St. Petersburg and eventual commitment to partitioning the Ottoman Empire. Apprehensive that Abdulhamid's popularity would lead to his rehabilitation, however, in

32 The sultan wrote in his memoirs that he was sad to turn away from France, which had influenced so much of his father's modernist policy, but the French occupation of Tunisia turned the Muslim world against France. Abdulhamid II, Siyasi Hatratum (Istanbul, 1974). It is well known that Abdulhamid offered his assistance to the Young Turks but was initially turned down. Eventually, Talat Paşa did seek that sultan's advice in 1917 and 1918 only be told that it was too late. The issue is discussed at length in Cemal Kutay, $\ddot{U}_{\zeta}$ Devirde Bir Adam (Istanbul, 1980). This is a biography of Fethi Okyar, a close friend and premier of Atatürk, and the only Young Turk leaders trusted by Abdulhamid. 
1909 the Young Turks replaced him with Sultan Reşat (Mehmet V) who became their docile instrument.

The period 1912-13 was a turning point in the history of the Young Turks and the Ottoman entry into World War I. The Unionists lost control of the government as a consequence of the by-elections of 1912, but regained it through a coup and assumed full power in January 1913. That year also marks the ideological shift to nationalism. After the Ottomans were defeated in the Balkan Wars and lost Albania, they began to view the ethnic Turks as the core group that should become the foundation of the state and assure its survival. They wanted to preserve the Empire by transforming it into a Turkish unitary state.

The nationalist organizations committed to cultural Turkishness, such as the Türk Yurdu and Türk Ocakları, became forums of ideological debate and inspiration for future policy. Meanwhile, the party's leadership, which had been recruited initially from among various traditionalist, Islamist, nationalist, and minority groups, gradually was reduced to just a dozen leaders and dominated by six or seven Ottoman-Turkish nationalists. Having functioned as a secret super-government, the Committee of Union and Progress decided in 1913 to become a full-fledged political party and expand throughout the country, where it already had a number of informal branches. It also replaced the sultan's imperial bureaucracy with its own loyal members and began a national policy of modernization and Turkification. Enver became minister of war and initiated a highly effective campaign to modernize the army.

Unfortunately, the Austrian annexation of Bosnia-Herzegovina in 1908 had undermined both the balance of power that had existed in the Balkans since 1878 and Sultan Abdulhamid's old policy of keeping the Balkan states apart. Italy, which had been promised Tripoli and Benghazi as early as 1900 , invaded and annexed those provinces in $1911,{ }^{33}$ and it sent arms to the Albanians as well as to Montenegro, ${ }^{34}$ distracting the Ottoman officers from helping the resistance forces in Libya.

The Albanians, Muslim and Christian alike, were in full revolt by 1912. The Ottoman government accepted most of their demands for autonomy as

\footnotetext{
${ }^{33}$ Shaw and Shaw, History of the Ottoman Empire, pp. 282-90.

${ }^{34}$ Reşat Halli, Balkan Harbi, 1912-1913 (Ankara, 1970).
} 
well as the union of Scutari (Ishkodra), Kosovo, Monastir (Bitola), and Janina provinces. The loss of Tripoli to Italy and the escalating Albanian demands for autonomy and independence then encouraged Bulgaria to ally with Serbia on 13 March 1912, with Greece on 29 May 1912, and with Montenegro on 24 September.

The First Balkan War started on 16 October 1912, after the Sublime Porte rejected the Balkan coalition's demands and Greece announced the annexation of Crete. The Ottoman army, which had been partially demobilized to prove the government's peaceful intention, was beaten on all fronts. The "ethnic cleansing" of Muslims that resulted-some half a million were killed and over one million made refugees-produced an extraordinary backlash in the Ottoman state. The growing ranks of nationalists demanded decisive action, ${ }^{35}$ and they blamed the old guard in İstanbul, who had regained power amidst the crisis created by the Albanian revolts.

The Albanian revolts challenged the old concept of Ottoman-Islamic solidarity and Sultan Abdulhamid's view that the Albanians "are our brothers in religion and superb soldiers who provided us with officers and officials" 36 . Previously, the Ottoman government had ruled Albania through feudal families who remained loyal to İstanbul as well as to their native customs, land and culture ${ }^{37}$. Likewise, Albanian intellectuals had been important in the Young Turk movement, but after 1908 they increasingly opposed the CUP's centralization policy and the idea of an Ottoman nation unified by a common Turkish language. Ultimately, the Albanian opposition was represented by Ismail Kemal, who belonged to a feudal family of Avlonya (Vlore) and had occupied high positions in the Ottoman government. The last of six Albanian revolts started on 2 March 1912 with some support from the Hürriyet and Itilaf party deputies in the Ottoman Parliament who wanted to undermine the Young Turks' government. Faced with their

${ }^{35}$ McCarthy, Death and Exile.

${ }^{36}$ Karal, Osmanls Tarihi, vol. 5, p. 240.

${ }^{37}$ Ahmet Cevdet Paşa, the Ottoman historian who visited Albania in the nineteenth century, reported that the Catholic and Muslim Albanians intermarried, that Catholics used the Muslim imam to officiate their marriages to a second, third and fourth wife, and that Catholics and Muslims fought beside each other and visited the graves of each other's war martyrs. Cevdet Ahmet Paşa, Tezakir (Ankara, 1953-1967), 4 vols. pp. 283-6. 
opposition as well as the pressure of the Halaskaran Zabit (Savior Officers), the government resigned on 16 July.

On 20 July, Sait Paşa, premier under Abdulhamid, was replaced by Gazi Ahmet Muhtar Paşa (1839-1918), known as a friend of the British. Because the new government termed above party or the "Grand Cabinet"-regarded the Albanian revolt as an uprising against the oppression of the Union and Progress Party, it accepted the Albanian demands, dissolved Parliament, and decided to hold new elections to end CUP rule and perhaps the committee itself. Gazi Ahmet Paşa was an honest and respected soldier, but he naively believed that the great powers would prevent a war in the Balkans and safeguard Ottoman integrity. The war started in October; by November 1912 the Ottoman troops, as mentioned, had been defeated on all fronts. At the London conference of May 1913, the Ottoman government relinquished all claims to the lands west of a line extending from Midia on the Black Sea coast to Enez on the Agean Sea. The new line, about 100 miles west of İstanbul, left Edirne (Adrianople), the second Ottoman capital, in the hands of the Bulgarians.

The Ottoman defeat in the First Balkan War resulted from a lack of training, supplies and political acumen and from poor administration. The failure of the government of Gazi Ahmet Muhtar Paşa to prevent the Balkan War symbolized also the failure of the old order and the folly of trusting Britain and France. All of this enabled the CUP to stage a comeback with a new policy of modernization. On 23 January 1913 the Committee ousted Kamil Paşa, a very pro-British premier who had replaced Gazi Ahmet Muhtar and was ready to sign an agreement leaving Edirne to Bulgaria. The new premier, Mahmut Şefket Paşa, was "a Prussian in everything but name," while his Cabinet consisted mainly of Unionists. He was assassinated on 15 January $1913,{ }^{38}$ giving the Unionists an opportunity to remove their adversaries and consolidate their hold on the government. Sait Halim Paşa,

38 The plot, arrest, and punishment of the plotters are related in detail in Djemal Pasha, Memories of a Turkish Statesman, 1913-1919 (London, 1922; New York, 1973). For Turkish version, which includes attacks on several individuals omitted in the English version, see Cemal Paşa, Haturalar (İstanbul, 1959). Among the conspirators arrested, tried and executed was Damad Salih Paşa, the son of Hayreddin Paşa of Tunisia, who was related to the imperial family. His execution, despite the intervention by the palace and the French, indicated that the CUP was to assert its independence and power over the palace and the country. 
already minister of foreign affairs, became premier, Talat interior minister, and Cemal military governor of Istanbul.

The Second Balkan War started on 29 June 1913 with a sudden Bulgarian attack on Serbia and Macedonia and ended with the defeat of Bulgaria, enhancing Unionist fortunes. It removed Bulgaria as an immediate military threat, made a new anti-Ottoman Balkan alliance impossible, and permitted the Unionist leaders Talat and Enver to recapture Edirne and the lands beyond the Midia-Enez line. It thus turned Enver into a hero of mythical proportions ${ }^{39}$.

The Second Balkan War also had unforeseen results. The British viewed the capture of Edirne, against their advice, as proof of the Young Turks' desire to reestablish the Empire. Meanwhile, France grew distant because of its closeness to Russia, ${ }^{40}$ and Italy occupied the Dodecanese Islands, which Istanbul did not insist on getting back until early 1914 , lest they be occupied by Greece.

The Young Turk leaders feared both Russia's rapprochement with Great Britain and the latter's efforts to win over Italy. By 1914 the British-Russian agreement of 1907 had brought London into the French-Russian military alliance of 1893-94 (the Triple Entente) and increased the Young Turks' suspicions that the Allies were bent on dividing up the Ottoman Empire. So too, had the Russian decision in 1913 to complete its rearmament by 1916. Furthermore, the Balkan War strengthened Serbia and weakened AustriaHungary as the guarantor of peace in the Balkans. Serbia, like Russia, feared that the Muslims in Kosovo, Bosnia-Herzegovina, and Thrace remained loyal to Turkey and could prove troublesome if Turkey continued to modernize and remain in the Western camp.

Russia also reasserted its role as protector of Christians in the Ottoman Empire by espousing Armenian demands for autonomy in Eastern Anatolia.

${ }^{39}$ The recapture of Edirne caused a flood of adulatory writings and forecasts by religious men and astrologers, one of whom was ever present around him, that Enver would revive the Empire and avenge all the humiliations it had endured for a century. Some of Enver's sudden, unpredictable actions resulted from these artificially inflated expectations, which also played a part in his urge to enter World War I.

${ }^{40}$ Cemal Paşa, Hatralar, p. 48, claimed that the British opposition to the taking of Edirne "threw off London's mask and showed its true face". Actually, Enver's action conflicted with the London agreement. 
Although the Armenians constituted just one-fifth of the population in the area and were not Orthodox Christians, in 1913 the Ottoman government unwillingly accepted Moscow as the Armenians' protector, a role previously performed by London ${ }^{41}$.

Greece, on the other hand, refused to sign the peace agreement ending the Balkan War and supported the anti-Ottoman activities of the Greek inhabitants of Western Anatolia. When clashes occurred between Muslim refugees from the Balkans and the Greeks of the Aydin (İzmir) province, they were portrayed as massacres organized by the Young Turk government against the Christians. When a commission organized by the government with the approval of the British, French, and German ambassadors ascertained that the Greeks were the real aggressors, Eleutherios Venezelos and Talat paşa agreed in 1914 to exchange the Greeks from the coastal regions of Aydın with the Muslims of Greek Macedonia. The full exchange, however, did not take place until 1926, after a Greek army that had invaded Western Anatolia between 1919 and 1922 was defeated by the nationalist forces of Mustafa Kemal.

\section{The Aftermath of the Balkan War}

Following the Balkan defeat, the CUP government decided to strengthen the army with the help from Germany, which had been advising the Turkish military for over thirty years. The idea of inviting in a German military mission originated with Mahmut Şefket Paşa, rather than Enver, and after Şefket's assassination it was promoted by Ahmed İzzet Paşa, the war minister. Consequently, General Otto Liman von Sanders came to İstanbul, ${ }^{42}$ as head of the German mission, despite his commission in the Ottoman army. On 3 January 1914 Enver became minister of war and rose to chief of

41 The Armenian question and its use by Russia to promote its own interests loomed greatly in the minds of the Young Turks and led to the evacuation of thousands of Armenians after Russian troops began to march into Eastern Anatolia. Practically all the Turkish leaders' memoirs dealing with the First World War devote long chapters to the Armenian question: $M$. Kasım, Talat Paşanın Anılan (İstanbul, 1986), pp. 57-140; Djemal Pasha, Memoirs of a Turkish Statesman, pp. 241-302; Mahmut Muhtar, Maziye Bir Bakış (1925, repr. İstanbul, 1941). Muhtar was the Ottoman ambassador to Berlin but was not informed about the secret German-Ottoman treaty of 1914 .

42 Otto Liman von Sanders, Five Years in Turkey (Annapolis, 1927); Cemal Paşa, Haturalar, pp. 68-70. 
staff over the opposition and criticism of the older generation of officers. Although the Russian, French, and British ambassadors saw Sanders's appointment as the first step towards an Ottoman-German alliance, it seems to have been intended chiefly to improve the training of the key First Army. Germany agreed to send the mission only after the Turks had consolidated their military position in Thrace, and just a few of the mission's seventy German officers held key posts in the war ministry. Thus, one cannot argue, as the British claimed, that the mission took control of the Turkish army ${ }^{43}$. The need to reform the military also prompted Cemal Paşa's appointment to the admiralty, where ironically, he implemented the recommendations of Sir Arthur H. Limpus, chief of the British naval mission to Turkey $y^{44}$.

A the same time, Turkey entered into negotiations with the British arms supplier Armstrong-Vickers, further demonstrating that the Ottoman rearmament was guided by considerations of quality, price, and financing rather than politics. After the Kaiser's visit to the Ottoman lands in 1889, the German arms firms of Krupp and Mauser as well as the shipbuilder Schichau had achieved a near monopoly in supplying arms and torpedo-boats. Germany subsequently lent the Porte 1.6 million marks (30 percent of which was held back for interest and expenses) ${ }^{45}$. But within a decade the balance of arms procurement had begin to shift to Britain and France.

Coming to power in 1908, the Union and Progress government developed a plan to counteract Greek naval power by building six battleships, twelve destroyers, an equal number of torpedo-boats, and half a dozen submarines ${ }^{46}$. By 1913, most of these orders had been placed with the British firms of Armstrong-Vickers and John Brown, which also acquired the

43 Jehuda L. Wallach, Anatomie einer Militaerhilfe: Die preussich-deutsche Militarmissionen in der Türkei, 1835-1919 (Düsseldorf, 1976). On German influence in the Ottoman Empire, also see İlber Ortayl, Ikinci Abdulhamid Döneminde Osmanlı Imparatorluğu'nda Alman Nüfuzu (Ankara, 1981).

${ }^{44}$ Cemal Paşa accused the old regime of neglecting the navy, which suffered from a lack of discipline. High-paid officers did not regularly report to duty (once assuming that Cemal's scheduled visit to headquarters would be cancelled because of rain) and opposed change. Cemal Paşa, Haturalar, p. 82.

${ }^{45}$ Nejat Gülen, Dünden Bugüne Bahriyemiz (İstanbul, 1988); and Conway's All the World's Fighting Ships, 1906-1921 (London, 1985), vols. 1 and 2, pp. 380-95, 390-4; Cemal Paşa, Haturalar, pp. 90-5.

${ }^{46}$ Even with the mounting threat of war, Ottoman leaders in July 1914 sent a mission to the Creusot arms factory in France to place new orders. In fact, most of the French and British arms could not be delivered because of the war. 
contracts to manage the Ottoman docks and arsenals, surmounting fierce German opposition. In addition, French naval yards had received orders for some thirty gunships, gunboats, mountain guns, and the like, costing over 100 million francs. Although the Germans retained their hold on the supply of ordnance to the army and their control of fortifications, including those of the Straits, they were unable to eliminate the French and the British from the Ottoman arms market. The British, however, viewed Sanders' mission as convincing proof that the Germans were taking control of Turkey.

London had long prepared itself for war with the Ottomans in the Levant. Lord Kitchener, during a visit to İstanbul in 1910, had become convinced that the British were out of the Ottoman Empire. A year later, while consul in Egypt, he supervised large-scale reconnaissance operations in Lebanon, Palestine and the Sinai desert. These were recommended by the Committee of Imperial Defence, but in fact camouflaged as an expedition of the Palestine Exploratory Fund ${ }^{47}$.

Still, the Young Turks tried to maintain the country's traditional policy of balancing the European powers. For example, they entrusted reorganization of the gendarmerie to the French General Bauman in 1912, and as late as July 1914 named another Frenchman inspector-general of finances.

Finally, in the spring of 1914 the Young Turks government began to realize that, no matter how well intentioned towards the Allies, its policies had alienated the French and British. Among the points of contention were internal matters such as its assumption of full power and growing authoritarianism, the ouster of pro-British officials including Kamil Paşa, and the presence of a large German mission as well as the recapture of Edirne against London's advice.

\section{The Decision to Enter World War I}

The government's sense of isolation seems to have been further compounded by Russian military movements in the East. Russia already had occupied Tabriz in 1911, had begun to incite the Armenian nationalists and

47 Juka Nevakibi, "Lord Kitchener and the Partition of the Ottoman Empire, 1915-1916", Studies in International History, K. Bourne and D. C. Watt, eds. (London, 1967), pp. 316-18. 
Kurdish groups in East Anatolia, and had become involved in negotiations to delimit the Turco-Iranian border ${ }^{48}$. Then, in May 1914, Tsar Nicholas II approached King Geogre V with the proposal to turn the Triple Entente into a military alliance preceded by a naval agreement. That same spring, Russia, which long had opposed Ottoman plans to increase defense capabilities by building a railroad in the Erzurum area, attempted to revive the question of the Straits. For Young Turks, all this implied that Russia was actively preparing for war against them ${ }^{49}$.

At first the leadership of the Young Turks sought an alliance with, or territorial guarantees from, the Allies. A delegation headed by Talat Paşa himself extended the customary good wishes to the tsar when he came to his summer residence in Livadia, Crimea. Unable to speak personally with the tsar, Talat broached the issue with Foreign Minister S. D. Sazanov, but nothing came of it. When Cavid Bey, the finance minister, approached Winston Churchill, the response was that any alliance or guarantees would violate British "neutrality" and potentially undermine efforts to attract Italy into the entente. Likewise, Lord Kitchener told the Ottoman ambassador in London, Ahmed Tevfik Paşa, that the members of the entente did not want Turkey to enter the war on their side ${ }^{50}$.

48 Ali İhsan Sabis, Harb Hatralarım, vol. 1 (1943 repr. İstanbul, 1990); vol. 2 (1951 repr. İstanbul, 1992). General Sabis (1882-1957), born to a military family, belonged to Enver Paşa's close circle. He participated as staff officer in the Balkan war and commanded several armies in World War I. He published his memoirs in the early 1940s and also a variety of articles pleading for the reconciliation of the allies with Germany in order to build a "common wall against the Soviets." In his writings, Sabis attacked some well known pro-Soviet Turks, as well as some leaders and went to jail for slander. His memoirs, which contain exceptionally enlightening information, have been scantly used, probably because of his political views. Sabis considered Sanders a mediocre commander, while the German described Sabis as an "intriguer" after Sabis cautioned Enver about Berlin's intentions to drag the Ottomans into the war. Sabis, like a large number of Turkish officers, wanted to delay the entry into the war until the spring of 1915.

49 Talat Paşa, in his memoirs, claims that Russia's plan was to use Bulgaria and Armenia (after helping the latter achieve independence) to encircle Turkey and cut off its communications with the Muslims of the Caucasus and then to occupy İstanbul. When the Russian ambassador in İstanbul proposed in 1914 a plan to combine the six East Anatolian provinces into a single unit to be administered by one general governor, Talat asked the Russian ambassador in Moscow to institute reforms in Turkistan. Talat Paşa'nın Anıları (İstanbul, 1986), pp. 29-31. Britain refused to send inspectors to East Anatolia because Russia opposed it, thus increasing further the Ottoman fears of a British-Russian collusion to divide the state.

${ }^{50}$ Cavdar, Haturalar, p. 315. 
Ottoman attempts to enlist French support also failed. Cemal Paşa, a dedicated friend of France and founder of the French-Turkish Friendship Society, was invited to visit France by the French government. Foreign Minister Rene Vivani was accompanying President Raymond Poincare on a visit to St. Petersburg that played a key part in unleashing World War I, so Cemal met with the director of political affairs. Cemal told him, "Take us [Turks] into your Entente and at the same time protect us against the terrible Russian threats," and the Central Powers will be encircled with an iron ring ${ }^{51}$. Cemal interpreted the French reply-that an alliance with Turkey needed the Allies' approval, which was very doubtful-to mean that Paris "was convinced that it was impossible for [Turkey] to escape the iron claws of Russia, and under no circumstances would [France] provide us help." ${ }^{52}$

Cemal left Paris on 18 July 1914 with the Legion d'honeur on his lapel but also with profound disappointment in French "friendship," and a new willingness to forget his dislike of Germany and its Kaiser. When Talat asked Cemal whether he could accept an alliance with Germany, he replied that he would "accept any alliance which would rescue Turkey from her present position of isolation." ${ }^{53}$ Already, government leaders had learned about the supposedly secret talks that had taken place in Egypt among representatives of the entente following Archduke Francis Ferdinand's assassination in Sarajevo ${ }^{54}$. In Egypt it was decided that the northeastern part of Turkey, the Straits, and İstanbul would go to Russia while most of the remaining parts of the Middle East were to be divided between Great Britain and France. The arrangements were later formalized in the Sykes-Picot Agreement of 1916, although the existence of an earlier partition agreement has not been ascertained.

${ }^{51}$ Cemal Paşa, pp. 113-4.

${ }^{52}$ Ibid., p. 106.

${ }^{53}$ Ibid., p. 108.

${ }^{54}$ Cemal Kutay, Sehit Sadrazam Talat Paşa'nın Gurbet Hatraları (İstanbul, 1983), vol. 2, pp. 869-74. Commentaries accompanying the memoirs of Talat Paşa are another unexplored Turkish source, although Kutay's scholarship has been questioned. For a Turkish view on partition agreements, see Yusuf Hikmet Bayur, "Dünya Savaşı Sırasında Osmanlı Devleti'nin Paylaşılması Hakkında Yapılan Anlaşmalar", Cumhuriyetin 50. Yildönümü Semineri (Ankara, 1975), pp. 31-47. 
The Ottoman government's isolation and fear of partition acquired immediate urgency when the assassination of the Archiduke made war between the Triple Entente and the Triple Alliance imminent ${ }^{55}$. Ottoman leaders and the general staff believed that Britain would want to use the sea route through the Straits to aid Russia, so London would occupy the Straits regardless of the Ottoman position in order to secure the supply route. (The British attempt to occupy the Straits in 1915 supported theirs assumption.) In addition, Istanbul feared that Athens, which had concluded a treaty of alliance with Serbia, would launch an attack in Thrace, possibly with Bulgaria's support.

On 18 July, Talat, Enver, and Halil (the head of the House of Deputies) began to meet secretly with Sait Halim Paşa, premier and foreign minister, to discuss an alliance with the Central Powers. Although at the last moment the group decided to approach Cemal, who now was ready to join any alliance, neither the cabinet, the Parliament, nor probably the sultan was informed about the initiative ${ }^{56}$. In sum, by the middle of July Germany appeared to promise a new order, while Britain and France represented a past of humiliation and exploitation and an imminent threat of partition.

Enver approached the German ambassador on 22 July but was rebuffed as many German officers considered Turkey a military and economic liability. Wilhelm II, however, overruled Wangenheim and approved the alliance with Turkey. Then it was up to the Young Turk leaders to win domestic support for the idea and draft the text. Cavid Bey, the finance minister, who was informed on the eve of the signing, opposed the alliance to the end and resigned, though he continued to serve informally. Meanwhile, on 1 August, London seized the Turkish battleships being built in Britain, thereby underscoring the Unionists' suspicions of London and their urgent need for an alliance to safeguard Turkey.

The chief provisions of the treaty-Articles 1 and 2-called for Ottoman intervention on the German side if Berlin became involved in a war with Russia over the Austrian-Serbian conflict. They also obligated Germany to

55 The Young Turk leaders were so alarmed by the initial word of the Sarajevo assassination that Talat and his friends spent the night in the prime minister's office awaiting additional news vie the telegraph.

${ }^{56}$ These issues are discussed at length by Bayur and Y. T. Kurat, "How Turkey Drifted into World War I", Studies in International History, Bourne and Watt, pp. 297-9. 
help protect the territorial integrity of Turkey and to leave Sanders's mission at the disposal of İstanbul. The treaty would remain in effect until 31 December 1918 unless renounced by either party ${ }^{57}$.

Three days after the treaty was signed, Enver told the Russian military attaché in İstanbul that if Russia quieted Turkish fears in the Caucasus, İstanbul would withdraw its forces from that front. He added that Turkey was bound to nothing but its own interest. But resulting talks with the Russian ambassador proved fruitless.

Instead, in a letter of 6 August Wangenheim expanded the provisions of the treaty after the German warships Goeben and Breslau sought asylum in the Straits from pursuing British and French vessels. Now Germany promised to assist the Porte in abolishing the capitulations, agreed not to conclude peace unless enemy-occupied Turkish territories were evacuated, and pledged to help Turkey achieve understanding with Romania and Bulgaria and receive a fair share in the spoils of war from the latter. Germany also agreed to support the return of the Aegean Islands to Turkey if İstanbul entered into a war with Greece and defeated it, and to help Turkey secure territorial contact with the Muslims of Russia through a small correction of the Eastern border. It further promised Turkey a war indemnity ${ }^{58}$. By increasing Turkey's stake in the war, Wangenheim's letter emboldened the hawks to support it. Nevertheless, the treaty's existence remained secret from more than half of the cabinet, from Parliament, which was soon recessed, and even from the Ottoman ambassador in Berlin, Mahmut Muhtar.

Despite the alliance with Germany, the Turkish government seemed to believe that although the war had already started, Turkey could somehow manage to stay out of it. Enver and many other leaders thought that the war would be over in six weeks or, at most, six months. Hence, Turkey declared itself neutral, and some German officers feared that Turkey might reconsider the alliance. The arrival of the Goeben and Breslau, however, gave Germany a decisive card, which could be played with the consent of Enver, the minister of war and head of the Ottoman forces, including, the German mission and warships.

${ }^{57}$ Die deutschen Dokumente zum Kriegsausbruch, no. 285, cited in Trumpener, Germany and the Ottoman Empire, p. 16.

${ }^{58}$ Trumpener, Germany and the Ottoman Empire, p. 28. 
The Goeben and Breslau originally had operated against the French, bombarding Bone and Philippeville on the north coast of Africa but had avoided battle with British as well as French warships by escaping eastward. Turkish authorities initially opposed the entry of the two German cruisers, but practically the same day, 6 August, the Ottoman prime minister realized that the refusal went against the alliance treaty. He informed Berlin that the cabinet had authorized the entry, although Turkey would maintain its neutrality. After the ships entered the Dardanelles, the Ottoman government "bought" them for 80 million marks so as to maintain the façade of neutrality ${ }^{59}$. In fact, Admiral Souchon, backed strongly by Berlin and Wangenheim, declared that the Kaiser was his commander and that the cruisers, though flying the Turkish flag, were German vessels; he would not receive orders from the Turks. Or, as Yusuf Hikmet Bayur has written, "The two Ottomanized cruisers would receive orders only from the Kaiser and would do what they pleased under the Ottoman flag." ${ }^{60}$

The British viewed the arrival of the ships as a definite sign that Turkey would go to war on the side of the Central Powers. The Amerikan ambassador, Henry Morgenthau, was more emphatic, writing in his memoirs that Turkey would inevitably join the war when Germany desired her assistance $^{61}$. Meanwhile, Admiral Limpus requested and was granted leave from his duties as naval adviser, probably at the suggestion of his own government. Indeed, Britain, which had warned that the German vessels would be sunk, had stationed warships at the exit of the Straits, effectively closing them until the end of the war.

The presence of the two German warships in Turkish waters alarmed many Turkish officers who feared Turkey would be dragged into the war before its army was ready to fight. A group of high-ranking staff officers in

${ }^{59}$ Bayur, Türk Inkilabı Tarihi, 1914-1918 Genel Savaşı (Ankara, 1982-83), vol. 3.

${ }^{60}$ Ibid., p. 86.

${ }^{61}$ Ambassador Morgenthau's Story (New York, 1918), pp. 18ff; Harry N. Howard, The Partition of Turkey: A Diplomatic History, 1913-1923 (Norman, OK., 1931), pp. 40-1. Cemal Paşa believed also that the German declaration of war on Russia on 3 August 1914 made the Ottoman entry inevitable. Morgenthau viewed Enver as dedicated to the German cause. General Sabis defined Enver not as a pro-German, but as a "Turkish patriot who trusted and believed in Germany." Sabis, Harb Hatiralarım, vol. 2, p. 55. Halil Bey in his memoirs claimed that the initial idea of the prime minister was to conclude a defensive alliance with Germany and that Wangenheim was involved in the talks with the premier as early as 15 July 1914. Halil Menteşe, Osmanlı Mebusan Meclisi Reisi Halil Menteşe'nin Anıları (İstanbul, 1986), p. 187. 
Enver's close circle worried that Enver's belief in German technology and hopes for a short war would induce him to push Turkey into the war, possibly for the reward outlined in Wangenheim's letter that had enlarged the alliance treaty ${ }^{\mathrm{i} 2}$. The largest group of officers in key positions, such as Ali İhsan Sabis, Hafiz Hakkı, and Kazım Karabekir, maintained that the Ottoman state should act according to circumstances and enter the war only in the spring of $1915^{63}$. The şeyhulislam and the ministers of education and justice also belonged to this group, but did not support the war at all. A third group opposed entirely to the war included the largest part of the intelligentsia and most of the population.

Some of the German officers, such as the second chief of staff, Fritz Bronsart von Schellendorf, and Liman von Sanders, the head of the mission, initially believed that the war decision should be left to the Turks and that Turkey should not enter the war before 1915. Another group of German officers, including Admiral Souchon, the naval attaché, and Ambassador von Wanghenheim, however, agreed with German headquarters that immediate pressure should be put on the British in Egypt and Iraq.

The halt of the German offensive at the Marne on 9 September 1914 and the setback to Austro-Hungarian forces on the Eastern front dashed expectations for a quick German victory. They also increased fears of a Russian advance into Central Europe, even after the decimating defeat inflicted by Germany on the tsar's armies at Tannenberg and the Masurian Lakes. Along with the initial Russian victory against the Habsburg army, the possibility that Italy might join the entente increased the German need to put pressure on the Russians in the Caucasus and on the British in Egypt. In this context, the German warships provided the means to achieve Turkey's entry into the war.

${ }^{12}$ Kazım Karabekir, who was the head of the intelligence section at general headquarters, wrote in his memoirs that the war party advocated Ottoman entry into the war as early as 16 August. The war party believed that a German victory was very near and was warned by German officers that Turkey should not miss the opportunity to acquire territories in the Balkans and the Caucasus. No decision was taken at a meeting convened for the purpose because of the possibility that Romania and Bulgaria would join in an anti-Turkish coalition. Finally the Germans realized that Enver alone could not decide on the war issue and that they had to win over other Turkish officers. Kazım Karabekir, Birinci Cihan Harbine Nasıl Girdik (İstanbul, 1995), vol. 2, pp. 265-98.

63 Sabis, Harb Hatıralarim, vol. 2, pp. 59-60. 
Souchon insisted on sailing his vessels out of the small Marmara Sea and into the Black Sea to help the Turkish sailors "become accustomed to seasickness." Although General Sabis and his colleagues were suspicious, Enver's approval allowed Souchon to take part of the fleet into the Black Sea during the first half of September. Next, Souchon asked to take the entire Ottoman fleet into the Black Sea, and this time Enver's approval overrode the Council of Ministers, under the condition that the fleet return from the Black Sea on the same day it set out. Enver then left for an inspection tour of Edirne and Bandırma and took along Sabis. Upon seeing the fleet sail out, the prime minister called Cemal, the navy minister, who ordered the fleet back to İstanbul, but Souchon replied that he would honor only the order from Enver's headquarters.

Sabis later recalled that suspicions about Souchon increased to the point that Sanders told Ambassador von Wangenheim that an incident in the Black Sea actually would strengthen the position of the Turkish anti-war party $^{64}$. But the Germans were more concerned by British preparations against Iraq. On 5 October Turkish general headquarters informed the naval command that it again had permission to sail into the Black Sea-this time for war training - but it was not to sail too far from the Straits. On 11 October Wangenheim informed the war party (Talat, Enver, Halil, Cemal) that Germany would provide a loan of about one billion marks and that "there was no obstacle to the (Turks') entry into the war." ${ }^{55}$

Only the hawks in the Ottoman cabinet had proposed to enter the war before spring. Their hand had been strengthened, however, on 8 September 1914, when the Ottoman government announced that at the beginning of October it was abolishing the hated capitulations. Although Germany did not recognize the decision until 1917, the huge public display of support for the announcement bolstered the war party and underscored the need to secure the abolition. Abolishing the capitulations played such an important part in Turkey's entry into the war because they had reduced Turkey to a European semi-colony and were regarded as the key obstacles to modernization. Even after winning its 1919-22 war of independence, Turkey refused to sign the peace treaty to protest British and French efforts to retain the capitulations. (The peace conference reconvened only when the Western nations agreed to abolish the capitulations and the Lausanne

${ }^{64}$ Ibid., p. 63; Karabekir, Birinci Cihan, vol. 2, pp. 316-7.

${ }^{65}$ Sabis, Harb Hatralarım, p. 68 . The loan amounting to 1.9 billion was paid in gold; the first shipment came on 16 October and the next on 21 October. Trumpener, Germany and the Ottoman Empire, p. 376. 
Treaty, which sanctioned internationally the creation of modern Turkey, was signed in 1923.)

German pressure to force the Ottomans into the war increased on 20 October 1914. Sanders, apparently on orders from German headquarters, told Enver that unless Turkey entered the war, he would render the Goeben and Breslau unusable and return with his mission to Germany, leaving Russia to defeat Austria-Hungary and occupy İstanbul. Kazım Karabekir, head of the intelligence section, recalled that in answer to his caution about Turkey's entry into the war, Sanders hit the table with his fist and shouted:

What are we doing here when the Russians mass all their troops against the Austrians, and the British-gather at the front [in Europe]. We are here just spectators. Why are you keeping us here if you don't intend to enter the war? Your government is not keeping its word and is deceiving us. If you do not intend to enter the war you should tell us openly, so that we could go to defend our homeland ${ }^{66}$.

According to Karabekir, the Germans feared that Enver was still hesitant, and they wanted to neutralize his close associates, who opposed an early entry into the war ${ }^{67}$. At this point, Karabekir claims, Enver signed a secret agreement, prepared by General Bronsart von Schellendorf, the German chief of staff at Ottoman headquarters, to create an incident on the sea that would bring the Ottomans into the war. "The decisions of Enver to enter the war without informing even the head of the General Staff, who was his close friend and colleague [Hafiz Hakk1]," 68 wrote Karabekir, "was a heavy moral and judicial crime." ${ }^{69}$ Both Karabekir and Ali İhsan Sabis seemed to believe that on 25 October Enver authorized Admiral Souchon,

${ }^{66}$ Karabekir, Birinci Cihan, vol. 2, p. 332.

${ }^{67}$ According to Sabis, Enver asked both Hafiz Hakku and Bronsart, chief of staff, Ottoman $\mathrm{GHQ}$, to report to him about military measures to be taken if the Turkish and Russian Black Sea fleets ignited a war. Bronsart von Schellendorf proposed that the Turkish fleet (under Souchon) attack the Russian navy and achieve "superiority" on the Black Sea, that the sultan issue the call to Cihad after Russia declared war, that the Turkish forces engage the Russians in the Caucasus, that the Eight Army march to Suez and that actions be undertaken against Serbia and Romania. Sabis, Harb Hatralarım, vol. 2, pp. 76-8, text of memo in Karabekir, Birinci Cihan, vol. 2, pp. 374-5.

${ }^{68}$ Hafiz Hakk, one of the key officers in the general headquarters, had opposed Enver's plans for an early entry. He was an excellent commander but also very ambitious-some suspected that he wanted to take Enver's position as generalissimo. Enver neutralized him after his return from Germany by promoting him rapidly to commander of the Caucasian front where he died of typhus in January 1915. He left some written memoirs concerning only the Balkan War.

${ }^{69}$ Karabekir, Birinci Cihan, vol. 2, p. 353. It should be remembered that Karabekir wrote his memoirs in the Republic and probably exaggerated his accusation against Enver. Sabis, who belonged to the group opposed to early entry into the war, supports Karabekir. 
who had become the official commander of the Ottoman navy on 24 September, to engage the Russians when he deemed this suitable ${ }^{70}$.

The confrontation between Sanders and Enver coincided with the Russian offensive on the Warsaw front, which handed the Germans a harsh defeat. After 20 October, Enver either avoided contact with his close associates or tried to neutralize them. Karabekir was invited on the inspection mission to Bandırma while Hafiz Hakkı, Enver's deputy, was sent to Berlin.

Within days, the Russian and French ambassadors, warned by their intelligence services, informed Talat paşa that the Germans were prepared to use an incident at sea to bring the Ottomans into the war. Talat replied that such an incident would not occur without Enver's approval and that Enver would not betray his friends Hafiz Hakkı and Karabekir, who opposed immediate entry. Talat stated in his memoirs that because the entente believed Turkey was entirely dominated by Germany, he proposed a new provision to the alliance treaty, allowing Turkey to stay out of the war for some time. The cabinet accepted Talat's proposal and decided to send Halil Menteş along with Hafiz Hakkı to Berlin after the three-day Bayram Holiday (about 3 November). But on the eve of the Bayram, Souchon attacked the Russian fleet. "We did not know about this fact [the attack on the Russians] but like everybody else we believed that Enver was informed," Talat wrote ${ }^{71}$.

Karabekir, the intelligence chief, learned about the bombardment only on 30 October, after he went to his office. Sanders met him there with the "happy cry 'Gott sei dank' [sic] finally we are at war. The Russians came close to the Strait and attacked our navy which fired back and sank a torpedo boat, and forced the others to retire and then went to bombard the Russians ports."72 The public was informed the same day ${ }^{73}$.

${ }^{70}$ Sabis, Harb Haturalanm, p. 40.

${ }^{71}$ Talat Paşa'nın Haturaları, p. 40.

${ }^{72}$ Karabekir, Birinci Cihan, vol. 2, p. 360.

${ }^{73}$ Enver and Cemal Paşas defended the official view that the Russian ships attacked the Ottoman fleet although one of the Russian ships supposedly attacking the Ottoman fleet near the Straits was sunk close to the Crimean shores. It is known that Russia intended to neutralize the Goeben and Breslau and probably intended to mine the entrance to the Straits as implied by the answers of the Russian sailors captured by the Ottoman fleet. Karabekir, Birinci Cihan, vol. 2, pp. 365-7. 
Prime Minister Sait Halim Paşa, who had not been informed about the attack, was persuaded not to resign. He offered an indemnity for damages to Russia, but St. Petersburg, which already had recalled its ambassador; first insisted that the entire German mission and fleet leave Turkey then officially declared war on 3 November.

Although the ministers opposed to war, headed by Cavid Bey, resigned, Talat reported government officials and most members of Parliament were pleased with the Ottoman entry into the war. Like the general population, they all believed that a quick German victory would bring Turkey full freedom and security, ${ }^{74}$ not the death and destruction that followed.

Finally, it should be noted that the concept of Cihad played a significant role in the war plans of both Germany and Great Britain. Sultan Abdulhamid II had threatened to call upon the Muslims of India to rise against the Raj if London sought to dominate or partition the Ottoman state. Although a number of British leaders, including Lord Curzon, did not believe in the Cihad's effectiveness, Lord Kitchener and others thought it was likely to create unrest in India and undermine the loyalty of their Muslim troops. The Germans, for their part, had high hopes that the Cihad would disrupt the war efforts of the British in the Middle East and of the Russians. Specifically, the German high command believed that the Cihad, supported by pan-Turkish and pan-Turanist appeals, would incite Russia's Muslims to revolt against the tsar and serve, as an ideological catalyst for Young Turks nationalists to fight in the war ${ }^{75}$. The leadership of the Young Turks seems to have encouraged the German hopes and British fears of panTuranism in the belief that it enhanced the value of Turkey.

Actually, the revolution of 1908, the ousting of Abdulhamid, and the new sultan-caliph Reşad who had become a docile instrument of the Union and Progress leaders all had voided the caliphate of its religious essence and influence. True, the formal apparatus to issue the Cihad was intact, for the new Sultan Reşat (Mehmet V) had been installed as a bona fide caliph and continued to receive the religious homage of all Muslims. Because he was not, a truly sovereign sultan in full control of the temporal power to

74 Talat Paşa'mun Haturaları, p. 42.

${ }^{75}$ Karabekir, who supported a Turkish Anatolian nationalism, claims that the defeat in the Balkan War revived the idea of a Muslim union and pan-Turanism and that the Germans and Hungarians supported the latter ideal. Karabekir, Birinci Cihan, vol. 2, pp. 74-8. Actually, the issue was much more complex, and the idea of a Muslim union based on religion and a panTurkism relying on ethnicity was not compatible. 
administer the mülk, or territory, the caliph's influence was limited ${ }^{76}$. Moreover, the call to fight a holy war on the side of one Christian power against other Christian states was still unsettling to Muslims, although the caliph had set the precedent in the Crimean War by inducing the Muslims to help the Allies against Russia. In any case, General Bronsart von Schellendorf planned to ask the sultan to issue the call to Cihad soon after the declaration of war. Duly issued by the seyhulislam in the name of the sultan-caliph, ${ }^{77}$ the call was sent to Cemal Paşa in Syria and to Şerif Hüseyin, the emir of Mecca, who held the second most important position in the unofficial Islamic hierarchy.

In the Cihad call, the caliph angrily accused Russia of causing territorial losses to the Ottomans for three hundred years and of destroying with war, ruse, and intrigue "every [Ottoman] effort toward progress and renewal that could have enhanced our national strength and greatness." ${ }^{78} \mathrm{He}$ also accused Russia, Britain, and France of using every device to turn the Muslims against the caliphate and to deny the rights of the sultanate. The bulk of the call was a patriotic exhortation to Ottoman soldiers to fight for their homeland rather than a truly religious appeal; it consisted of five fetvas that justified in Islamic juridical terms the action against Russia, Britain, and France $^{79}$.

In spite of the pressure from İstanbul, Şerif Hüseyin of Mecca did not sanction the Cihad call. It also was challenged by a British counterproclamation issued in India as well as by a number of Muslim leaders, including Aga Khan, who questioned its validity ${ }^{80}$. Intense British propaganda accused the Young Turks' leaders of accepting money from the Germans and pressuring the caliph to follow their directives.

76 The new sultan's secretary, the noted novelist Halit Ziya Uşaklıgil, regularly reported the sultan's activities to the Young Turks. See his book, Saray ve Ötesi: Son Hatralar (Istanbul, 1940-41), 3 vols.

${ }^{77}$ Bayur, Türk Inkilabı Tarihi, p. 320.

78 Ibid., pp. 215-6.

79 The text of the Gihad and fetvas are found in addition in Karabekir, Birinci Cihan, vol. 2, pp. 384-400 and J. L. Lewis, "The Ottoman Proclamation of Jihad in 1914", Islamic Quraterly 19. January-June 1975, pp. 157-63.

${ }^{80}$ Most of the Muslim leaders, usually of older age and part of the establishment that enjoyed British and French support, claimed that the call to Cihad had no real justification. Islam as a faith was not threatened directy; the European war was not a religious war; the sultan was forced to enter the war against his will; and if Germany won the war, the Ottoman state would become one of its provinces. They stated also that Turkey lost its place as the representative of Islam because Turkey entered the war to achieve its own political goals rather than to fight for the future independence of Islam. Bayur, Türk Inkilap Tarihi, pp. 32-40, 214. 
The effect of the call to Cihad on Muslim soldiers in the British army was minimal. By contrast, in 1920, when the British forced the sultan to sign the Treaty of Sevres, dividing most of Anatolia, the Muslims of India and elsewhere overwhelmingly supported the Turkish nationalists under Mustafa Kemal, for that was a genuine national struggle.

The historian Karabekir, relying on Bayur's views, sarcastically summed up the attitude of Ottoman leaders: "Ottoman state dignitaries had much less faith in the Cihad than the Germans." von Sanders, and General Erik von Falkenhayn, chief of the German general staff, remained silently skeptical about the efficacy of the caliph's call until it failed $^{82}$. The call to Cihad did cause the British and Italians to fear attack by the fundamentalist Sanusya in Libya, ${ }^{83}$ but all in all, use of the call for mundane political purposes during World War I and against the forces of Mustafa Kemal from 1920 to 1922 considerably weakened the moral foundations of the caliphate and brought about its demise in 1924.

\section{Conclusions}

The Ottoman entry into World War I originated in the modernist generation's search for progress, independence, and freedom from the burden of the capitulations. Britain had persuaded Ottoman leaders to initiate the first reforms and had helped to maintain Ottoman territorial integrity against Russian expansionism but later abandoned the sultan. From 1875 on, the British sought to undermine the unity of the Ottoman state and to thwart its modernization while continuing to pose as its benevolent patron.

Elie Kedourie points out in his seminal study of British policy in the Middle East that even before Salisbury became foreign secretary in 1878, he favored bringing down the Ottoman Empire and partitioning it. As early as 1878, he tried to turn the Empire into a British protectorate, only to be impeded by policy disagreements among the Europeans and by the new economic and military strength the Ottoman state achieved with German technical assistance. Salisbury persisted in his scheming for the rest of the

${ }^{81}$ Karabekir, Birinci Cihan, vol. 2, p. 320.

${ }^{82}$ For the German attitude on Cihad see Trumpener, Germany and the Ottoman Empire, pp. $117-20$.

${ }^{83}$ For Arab-Turkish relations during the war years, see Hasan Kayalı, Arabs and Young Turks (Berkeley, 1997). 
century. For example, he proposed partitioning the state with Russia in 1898 and offered the tsar the entire Black Sea littoral and the area up to Baghdad, preserving the south for Britain and proposing to turn the Arab lands into colonies rather than independent nations. Along with most British, French, and Russian statesmen, he viewed the Middle East as a land of backwardness and the reforms as a thin veneer of European civilization ${ }^{84}$. Only Germany showed some genuine interest in Ottoman welfare; a few of its officers expressed respect for the Turks' ability to progress and become part of Western civilization.

Some elements of the Young Turks, especially those in the military, consequently grew up with deep animosity toward Britain and affectionate admiration for Germany. Meanwhile, the older generation of Ottomans and many intellectuals remained attached to France and England as sources of European civilization. The coup of 23 January 1913 and the assassination of Şefket paşa on 15 June 1913 enabled the Young Turks to replace those proBritish and pro-French statesmen with a truly modernist, national-minded group.

The process of change unleashed by the Young Turks in 1913-14 definitely shaped war decisions and postwar developments. The entry into the war, therefore, must be seen as part of a larger transformation not just the result of international circumstances. Turkey was prepared to fight Europe in order to become part of Europe.

The Ottoman state's immediate objective in allying with Germany was to preserve its territorial integrity and independence against the obvious threat from Russia. Compounding the danger from Russia, in the spring of 1914, the Ottoman government found itself isolated from its so-called friends in Europe and increasingly threatened by Greece and Serbia. When it attempted to secure an alliance with France, Britain, or even Russia, ${ }^{85}$ its efforts were rejected along with its demands for territorial guarantees. The consequence was the secret treaty of 2 August with Germany designed to end Ottoman isolation. Recovering lost territories in the Balkans and

${ }^{84}$ Elie Kedourie, England and the Middle East, (London, 1956), pp. 20-4.

${ }^{85}$ Enver Paşa told the Russian military attaché in İstanbul that if Russia quieted the Turkish fears in the Caucasus, the Turks would withdraw their troops. Russian Ambassador DeGiers advised Moscow to give territorial guarantees to Turkey, while the French told the Russian envoy in Paris that it would be "advantageous for us to draw Turkey to the number of our enemies in order to make an end of her." Isvolsky to Sazanov, quoted by Howard, The Partition of Turkey, p. 98. Both France and Britain appeared "too certain of an easy victory over Turkey to consider it worthwhile to make serious advances towards conciliation." Ibid., p. 102. 
establishing a link to Albania, though important to the Ottoman, now had relatively low priority given the conflicting interests of Italy, Austria-Hungary, and Bulgaria.

Ottoman leaders considered the alliance a great diplomatic victory, for, as Cemal Paşa put it, no European country would take on the burden of a country like Turkey. At this stage, most Turkish leaders assumed that Turkey would somehow reap the benefit of the alliance with a victorious Germanywithout engaging in an active combat. Enver even contemplated trying to enter the war in August, before it was too late.

The treaty was the work of a small core of CUP leaders-Enver, Talat and Cemal Paşas, and Halil Menteş-although several other people seem to have been aware of it. It was an old Ottoman tradition (carried on by the Turkish Republic) to entrust the conduct of foreign affairs to a few knowledgeable people and then persuade Parliament to accept their decision. The unusually strong opposition of Parliament and the general public to Ottoman involvement in the war further limited the number of the negotiators in this instance. At the same time, the need for ratification provided the Young Turks an escape door if needed.

Turkey was brought closer to the war by the entry of the Goeben and Breslau into the Dardanelles, but there is not convincing evidence that the ships' refuge was planned by Germany, ${ }^{86}$ or was an "exchange" for the Turkish ships embargoed by the British. Yet, the arrival of the German vessels allowed Turkey to expand the alliance treaty and increase its stake in a German victory. It also alarmed the Allies that Germany might use the ships to provoke a war and/or fight the Russian navy.

The overwhelming majority of the Turkish population, Parliament, and the cabinet initially opposed the war before many changed their opinion for the sake of solidarity. Among the military, the older officers and the antiUnionists opposed war at any time. The younger officers in key command positions believed the alliance treaty did not mandate Turkey's entry into the war before the spring of 1915, knowing that the unprepared army lacked weapons and logistical organization. Enver's close associate at general headquarters - Hafiz Hakkı, his deputy and close friend; Kazım Karabekir, the intelligence chief, and Ali İhsan Sabis, in charge of training and mobilization - all were against an early entry as apparently was Enver until late September.

\footnotetext{
${ }^{86}$ Ulrich Trumpener, "The Escape of the Goeben and Breslau: A reassessment", Canadian Journal of History 6 (March, 1971), pp. 171-87.
} 
The German pressure for Turkey's entry began after the armies of the Central Powers encountered serious setbacks at the Marne and in Galicia. Backed by monetary incentives (loans) and the terms of the treaty, the message seems to have been conveyed by Ambassador von Wangenheim, Liman von Sanders (who initially had agreed with the Turkish officers' spring schedule), and General Bronsart von Schellendorf, the German chief of staff at Ottoman headquarters. In Karabekir's view, they were on orders from Berlin to draw Russian troops from the Austro-Hungarian front. The Suez campaign, planned long in advance by the Germans, as well as the call to Cihad, would tie down British troops in the Middle East.

Generally thought always to have been a war hawk, Enver, seemed to have undergone some change of heart by the end of September. His close associates at Ottoman general headquarters indicated that because of their opposition to an early entry, he was willing to wait until spring but gave in to heavy German pressure about 20 October, when he accepted Bronsart von Schellendorf's memorandum as a plan of action. Admiral Souchon eventually received written orders from Enver to attack the Russian fleet and ports, and the war decision was a secret shared only by Enver and the Germans. If one is to believe their testimony, Interior Minister Talat, Prime Minister Halil, Hafız Hakkı, and Karabekir, Enver's closest associates, learned about the attack on the Russians only several hours after it took place, on 3 November 1914.

In sum, given the colonialist designs of Great Britain, France, and Russia and their opposition to the Turks' firm desire to modernize, Turkey's entry into the war appears to have been an act of ultimate desperation. Yet, it was also an act laced with hopes that the war would bring the Ottoman state unfettered independence, economic freedom, and recognition as a member of the European comity of nations ${ }^{87}$.

87 The Turks' zealous dedication to their independence and unhindered control of their country and army was evident in their endless efforts to expand their authority in the conduct of the war rather than follow German directives, to amend old treaties in their own favor, etc. Although bickering among war allies is a normal phenomenon, the quarrels of the Turks with the Germans and Austrians reflected deep feelings of mistrust on both sides. The Turks considered the Germans arrogant as well as ready to trade Ottoman interests to safeguard their own. The Germans, on the other hand, thought the Turks were underdeveloped, overbearing chauvinists using Germany to keep alive their moribund empire. At times, the Germans acted as the masters of the Turks' country, further inflaming friction between German and Turkish officers. Enver agreed not to remove Sanders from his position after the Germans consented to limit his authority. The sudden death of Ambassador von Wangenheim on 25 October 1915 pushed aside for a while the quarrel over who was the real master of the Ottoman Empire. The new ambassador, Paul von Woldd-Metternich, was unpopular with the Turks from the start 
According to many British and German statesmen and military officers, Turkey's entry prolonged the war for two years and allowed the Bolshevik revolution to incubate and explode. It shattered the image of the "sick man of Europe", coined by Tsar Nicholas I and espoused by Europe to justify the partition of the Empire, for "the sick man of Europe" refused to die ${ }^{88}$.

Although the First World War ended with the total defeat and disintegration of the Ottoman Empire, ironically that disintegration freed the Turks from the burden of maintaining an obsolete imperial order and opened the door to fulfillment of their hopes for true modernization, independence, and nationhood. The entry of Turkey into NATO in 1952 and the acceptance of its candidacy for membership in the European Union in 1999 were the culminating points of process of modernization and nation formation that started in the latter part of the nineteenth century and went through decisive phase in 1914-18 and 1919-22. The defeat in World War I was thus a victory in disguise.

\section{ANNEX}

Attempts to identify the leaders of the war party have focused on Enver paşa, then Talat and Cemal paşas, followed by Halim (Menteş), who headed the House of Deputies, and Sait Halim Paşa, the prime minister and later foreign ministers. Closer examination of the background and public careers of these men in the following very short biographies, should, therefore, shed more light on the Ottoman entry and their part in it. (There are extensive biographies in Turkish for each one of these Young Turks leaders.)

İsmail Enver Paşa was born in İstanbul, the son of a minor bureaucrat who had immigrated from Macedonia. Graduating from the war college in 1902, he served in the Third Army in Macedonia, joined the Freedom Society in 1906, and played a leading role in the 1908 revolution. He then

\footnotetext{
because of his failure to understand the reforms of the Young Turks, whom he regarded as underdeveloped. Some ten moths later, in October 1916, he was replaced by Richard von Huhlmann. Obviously, the change of ambassadors during wartime indicated a basic difference of philosophy. These are numerous cases of German-Turkish friction and examples of parliamentary missions sent to soothe relations between the two allies. See Frank G. Weber, Eagles on the Crescent: Germany, Austria, and the Diplomacy of the Turkish Alliance, 1914. 1918 (Ithaca, 1970), pp. 190-2; and Trumpener, Germany and the Ottoman Empire, pp. 94-265.

88 The battle at Galipolli in 1915-16 that ended in a massive defeat of the British navy and its expeditionary corps was won almost exclusively by Turkish troops under the command of Mustafa Kemal. The same troops then inflicted a devastating defeat on the Greek invasion force.
} 
spent two years, 1909-11, in Berlin as Ottoman military attaché before serving in the Libyan war of 1911 as head of the resistance forces. His dashing youth, heroism in the Libyan war, and nationalism won him a popular following even before he conducted the coup of 1913 and reconquered Edirne. Becoming minister of war on 3 January 1914 and chief of staff five days later, he rejuvenated the army by entrusting key positions to young colleagues from his service days in Macedonia. On 5 March 1914 he married the sultan's niece Naciye, to whom he had been engaged in 1911, adding a romantic imperial glow to his name. Highly adventurous and emotional, Enver viewed himself as specially destined by Providence for military victory and national grandeur. Under his leadership, the army suffered heavy casualties in the offensive against the Russians at the Sarıkamıs in 1915, but he retained his power and fame. After the Ottoman defeat in 1918, however, Enver fled to Berlin, Moscow, and finally Central Asia, where he headed the local guerillas until killed by the Bolsheviks in 1922.

Enver and Mustafa Kemal (Atatürk), who were diametrically different in personality, thinking and organizational ability, also disliked each other. Mustafa Kemal had opposed the involvement of the military in politics, so Enver kept him in obscurity despite his brilliant success at Gallipoli in 1915. Nevertheless, Enver still enjoys great popularity among Islamists and nationalists in Turkey while most other Young Turk leaders, except for Talat, are all but forgotten.

Mehmet Talat was the true architect of the domestic policies of the Young Turks. Born in a village near Edirne, the son of a Turkish minor notable, he received his education in the local school and became a Union and Progress member as early as 1890, earning the reputation of a veteran freedom fighter. He taught Turkish at the Jewish school in Edirne and was the founder of the Freedom Society that was responsible for the 1908 revolution. He also headed a Freemason lodge.

Talat represented Edirne in the House of Deputies, was minister of the interior from 1913 to 1917, and became sadrazam, or premier, in 1917. When the Ottomans accepted defeat in 1918, he fled to Berlin and was murdered by an Armenian in 1921. Talat was a man of integrity ${ }^{89}$, a

${ }^{89}$ Talat did not hesitate to remove from the governorship of Trabzon a former director of Law School in Salonica and an important Unionist, Mehmed Cemal Azmi, for usurping the money of deported Armenians. Cavdar's book is a lengthy biography of Talat. 
dedicated modernist and nationalist as well as a very astute political leader. Also man of action, he liked to operate in secret and play his cards carefully although Enver seemed to prevail over him. He was said to be a Bektashi as well as a secular-minded and devoted believer, however contradictory it may sound.

Ahmed Cemal Paşa came from a middle-class family and after graduating from the War College in 1895, was attached to the Third Army in Salonica. There he joined the Freedom Society and, through it, the Union and Progress Society. He became a member of the ruling Central Committee in 1908 and governor of several important provinces before becoming minister of public works. Cemal was appointed minister of the navy in 1913 and then commander of the Fourth Army, which started the unsuccessful Egyptian offensive. Cemal was a disciplined, honest, and well-meaning person, who initially opposed entry into the war. His unfavorable reputation comes from his stern administration in Syria, during which he hanged many Arab leaders and intellectuals for supposedly plotting against the Ottomans. In 1918 he escaped abroad but was assassinated by Armenians in Tiflis.

Halil Menteş (also Menteşe), a loyal follower and friend of Enver to the end, was descended from an ayan (upper-class notable) from Milas in west Anatolia. He grew up in İzmir and studied at law Schools in İstanbul and Paris. Upon returning home, he engaged in farming until he was elected a deputy in 1908. Halil became the speaker of the House of Deputies and played a key role both in negotiating the secret alliance with Germany and in recessing the House, where the alliance faced likely opposition. He became foreign minister in 1915 when Sait Halim paşa was dismissed for opposing Enver's aggressive war plans, then minister of justice in 1917. A nationalist, Halil did not hesitate to defy and mistreat the Germans when they refused to make a loan for the defense of Anatolia unless the Turks paid immediately for the completed sections of the Anatolian railroad. He even advocated ending the German monopoly on railroad construction as well as abolishing the treaties of 1856, 1871, and 1878, claiming they infringed on Turkey's sovereignty.

Mehmet Sait Halim Paşa, or Prince Halim, was the grandson of Mehmet Ali, the founder of modern Egypt. Well educated, urbane and rich, he was an important modernist, liberal intellectual whose work Buhranlarımız (Our crisis) is still a good source for studying the attitudes and shortcomings of 
the Ottoman elites ${ }^{90}$. He also believed in a Muslim Union. Halim was appointed to the Council of State in 1888 but became an opponent of Abdulhamid's absolutism and fled to Paris, where he became a financial supporter to the Young Turks. After 1908, he returned to İstanbul to serve as general secretary of the Union and Progress Party, foreign minister, and from 1913 to 1917, grand vizier. Although Halim was pro-Western and opposed to war, he was easily manipulated and influenced and so was persuaded to sign the secret treaty with Germany. Arrested in 1919, then released, he went to Rome in 1921 and was murdered there by an Armenian.

Several other leading Unionists require mention. The teacher and financier Cavit Bey was a dönme (seventeenth-century Jewish convert of Sabatai Sevi) from Salonica. Pro-Western and opposed to Turkey's entry into war, he resigned from the cabinet in protest but remained active behind the scenes. Nazım Bey, a physician educated in Paris, also was influential behind the scenes, especially in persuading the revolutionary Freedom Society of Salonica to join the Union and Progress Society of Paris. He and Cavit were hanged in 1926 for planning the aborted assassination of Mustafa Kemal.

The biographies of the Unionist leaders indicate that they did not come from a single social class, ethnic origin, category of wealth, or similar grouping. Talat Paşa, their leader, had the humblest origin and was the least educated but the most virtuous. When he died, he left practically no wealth.

The Unionists were linked their elitist philosophy and Ottomanist national identity, which separated them from the Tanzimat (pre-1876) generation - and ultimately from the Republican-Kemalist one, although there was a high degree of continuity between them and the Kemalists ${ }^{91}$. The Unionist leaders were committed not only to science, technology, and modernization, but also to a rather unique form of populism designed to secure them popular backing against the sultan and to legitimize their modernist reforms. Although many were basically anti-monarchists and partly positivists, they were aware of the popularity of both the monarchy

${ }^{90}$ The last edition was published in 1983. See M. Hanefi Bostan, Bir İslamcı Düşünür: Said Halim Paşa (İstanbul, 1922). A thesis about him is being completed at McGill University. For a history of the German personnel involved in Turkish affairs, see Ulrich Trumpener, "Germany and the End of the Ottoman Empire", in The Great Powers and the End of the Ottoman Empire, ed. (London, 1984), pp. 111-40.

${ }^{91}$ For the changing origin, roles, and orientation of the Turkish elites from 1870 to 1995 , see my article to appear soon in a book edited by Erik J. Zürcher and George Hazai. 
and Islam among the masses and concealed their true feelings and intentions until the appropriate moment. Muslims all, their basic mutual bond was Islam, which they viewed as a secular culture anchored in the Ottoman past rather than as a faith.

As Ottoman nationalists, the leaders of the Young Turks were determined to achieve full independence, territorial integrity, and freedom of action for their state. These foreign policy objectives were the prime motive for their alliance with Germany and entry into the war. Yet there were two major contradictions in their vision. First, they were striving to put down the national claims of the Macedonians, Armenians, Arabs, et al., while promoting their own brand of Turco-Islamic-Ottoman nationalism. Second, they were fighting Europe's political hegemony while coveting its science and progress as a means to strengthening their own Empire. These contradictions ultimately were solved by the war. 
